\title{
A perspectiva de professores da Educação Infantil em um espaço escolar inovador
}

\author{
The perspective of early childhood education teachers in an innovative school space \\ La perspectiva de los docentes de educación infantil de um espacio escolar innovador
}

Recebido: 15/10/2021 | Revisado: 22/10/2021 | Aceito: 28/10/2021 | Publicado: 31/10/2021

\author{
Clara Cabral Neves Martinho \\ ORCID: https://orcid.org/0000-0002-7395-7570 \\ Universidade de Brasília, Brasil \\ E-mail: clarinhaneves11@gmail.com
}

\begin{abstract}
Resumo
Com o objetivo de compreender o modo como tem ocorrido o processo de construção de um espaço escolar inovador, o artigo estabelece como princípio a perspectiva dos professores que, implicados nesse caminho, visam à valorização da criança e de suas questões no próprio processo de construção. Na fundamentação teórica, busca subsídios, entre outros autores, em Walter Kohan, Walter Benjamin, Jorge Larrosa, Miguel Arroyo, Edgar Morin, Polianne Delmondez, José Pacheco, Regina Pedroza, Paula Sibilia e Lúcia Helena Pulino. A investigação, apoiada na metodologia qualitativa, inspira-se na cartografia com procedimentos de observação, de entrevistas semiestruturadas e rodas de conversa com os educadores, bem como de registros em diário de campo. No final, destacam-se alguns fatores como possíveis contribuições: a construção do lugar como possibilidades de compreensão, problematizações e realização de um espaço escolar que considere a valorização da criança; a construção coletiva de uma escola; o papel de pais e mães na sociedade contemporânea; e o desafio de tornar-se educador, por meio da reflexão sobre o que pode ser a educação que queremos: sem respostas ou soluções a aplicar, mas com a formação de uma comunidade em constante reflexão, mostrando-se como lugar único e essencial de transformações.
\end{abstract}

Palavras-chave: Infância; Educação infantil; Formação de professores.

\begin{abstract}
This dissertation aimed to understand how the process of building an innovative school space by its members has taken place. It established as a principle the perspective of the parents, mothers and educators involved in this path, who seeks the appreciation of the child and his issues in the construction process itself. In the theoretical basis, it sought the support of Walter Kohan, Walter Benjamin, Jorge Larrosa, Miguel Arroyo, Edgar Morin, Polianne Delmondez, José Pacheco, Regina Pedroza, Paula Sibilia and Lúcia Helena Pulino. The research, based on the qualitative methodology, with inspiration in cartography with observation procedures, semi-structured interviews and discussion with teachers, and field diary records. In the end, some factors were understood as possible contributions: the construction of the place as possibilities of understanding, problematizations and realization of a school space that considered the valuation of the child; the collective construction of a school; the role of fathers and mothers in contemporary society; and the challenge of becoming an educator, through reflection on what education can be: without answers or solutions to be applied, but with the formation of a community in constant reflection, showing itself as a unique and essential place of transformations.
\end{abstract}

Keywords: Childhood, Child education, Teacher formation.

\section{Resumen}

Para comprender cómo se ha desarrollado el proceso de construcción de un espacio escolar innovador, el artículo establece como principio la perspectiva de los docentes que, involucrados en este camino, tienen como objetivo la valoración de los niños y sus problemáticas en el propio proceso de construcción. En el fundamento teórico se buscan subvenciones, entre otros autores, en Walter Kohan, Walter Benjamin, Jorge Larrosa, Miguel Arroyo, Edgar Morin, Polianne Delmondez, José Pacheco, Regina Pedroza, Paula Sibilia y Lúcia Helena Pulino. La investigación, sustentada en metodología cualitativa, se inspira en la cartografía con procedimientos de observación, entrevistas semiestructuradas y círculos de conversación con educadores, así como registros en un diario de campo. Al final, se destacan como posibles aportes algunos factores: la construcción del lugar como posibilidades de comprensión, problematización y creación de un espacio escolar que considere el valor del niño; la construcción colectiva de una escuela; el papel de los padres y madres en la sociedad contemporánea; y el desafío de ser educadora, a través de la reflexión sobre lo que puede ser la educación que queremos: sin respuestas ni soluciones para aplicar, pero con la formación de una comunidad en constante reflexión, mostrándose como un lugar único e imprescindible para las transformaciones.

Palabras clave: Infancia; Educación infantil; Formación de professores. 


\section{Introdução}

Pensar coletivamente um espaço escolar, sob a perspectiva que se procura nesse contexto, é, no que diz respeito aos tempos da infância e educação, conceber que "a tarefa de educar as crianças consiste em fazer durar a infância todo o tempo possível" (Skliar, 2012, p.24), ou seja, planejamentos, atividades, brincadeiras, avaliações, reuniões, espaços e relações devem perder um tanto do peso que têm na maioria das escolas para dar lugar ao trabalho de educar, ao tempo da infância no que ela realmente é e deixá-lo prevalecer. Assim, caminhar para um espaço-tempo que dê à criança protagonismo, atenção e cuidado, de forma a deixar que o seja, e educar aprendendo com ela, a partir dela. Dessa forma, a pesquisa tem como objetivo compreender os caminhos do processo de construção de um espaço escolar inovador considerando seus membros participantes: pais, mães, crianças e educadores.

A pesquisa foi realizada em um espaço escolar no qual, há aproximadamente três anos, alguns pais, mães e educadores se juntaram para pensar, repensar e construir, no Distrito Federal, um ambiente que valorizasse o tempo-espaço da infância, a vivência e o contato com a natureza, a alimentação orgânica e saudável, as artes e a corporeidade como meios de aprendizagem. Tomaram-se por base os processos de tornar-se mães, pais e educadores em prática diária de coletividade, liberdade, autonomia, criatividade e gestão democrática, e, principalmente, as direções que as próprias crianças apontavam para a organização dos dispositivos e ritmo da escola.

O sonho desse espaço mistura-se com o imaginário da pesquisadora quando pensava sobre suas escolhas profissionais. Sempre quis ser professora - como a mãe e as boas educadoras que teve na infância -, e o sonho ficava em seu canto, esperando um dia acontecer. Anos se passaram, e, após o nascimento da primeira filha, atendendo ao chamado de algumas mães que estavam retornando ao trabalho e procuravam um lugar para seus filhos e filhas ainda tão pequeninos, sem encontrar aquilo que desejavam, o sonho começou a tornar-se realidade no quintal de sua casa, onde um espaço ia se formando, ganhando cor e som de crianças, tomando formas e criando cantinhos de brincar. A cada novo dia, uma nova experiência - sempre vindo da observação e da brincadeira com alguma das crianças desse grupo -, mais uma ideia surgia para construir aquele espaço.

E assim foi crescendo a sementinha da escola. Uma amiga que ficava encantada pelo relato da outra amiga que já fazia parte desse coletivo, um pai que ficou sabendo pelo colega de trabalho, enfim, os relatos das famílias que estavam construindo esse lugar espalhavam-se, e mais pessoas iam chegando. Cada uma com a sua história particular ia se colocando naquele grupo e agregando novos conhecimentos, outras experiências e olhares para crescer e fortificar um pequeno espaço escolar para as crianças.

A proposta pedagógica foi sendo construída em coletivo, pensando o que era objetivo de formação, aprendizagem e desenvolvimento para cada um dos sujeitos que estariam envolvidos. Inspirações em outras pedagogias, incorporação de atividades e logísticas que cada um já tinha vivido ou visto em outros espaços. Assim estava sendo desenhada toda a proposta desse espaço, trazendo sempre seus princípios básicos que não seriam deixados para trás - o contato com a natureza, a alimentação orgânica e saudável, as artes e a corporeidade por meio do brincar livre o do contato afetivo com as crianças.

Atravessado pela simplicidade e valorização das relações humanas, esse espaço é hoje composto por uma grande área verde com balanços para bebês e outros para crianças pequenas, em cujo movimento elas cantam e se divertem com o vento; um tanque de areia - cuidadosamente encomendada de uma comunidade localizada próximo de um rio e que faz o trabalho de reflorestamento - com alguns baldinhos, carrinhos e pazinhas com que a areia se transforma em bolos, tortas, castelos e casas das formigas (que são observadas nos caminhos que fazem enquanto as crianças brincam); uma casinha de madeira construída por dois pais na primeira vivência escolar, ainda no início da história da escola; uma casinha da árvore que conserva as formações descontínuas próprias da madeira natural, incluído o tronco de uma árvore que já estava no local e que passa por dentro da casinha (feita por outro pai); um brinquedo "trepa-trepa" de madeira com várias formas de escalar e escorregar acompanhado de três burrinhos - cavalinhos, vaquinhas, girafas - construídos por um pai da escola a pedido da coordenadora que observava a 
vontade das crianças de brincar de escalar, cavalgar e se esconder em cantinhos. Movidas pela prática do dia a dia, as educadoras solicitaram um banheiro próximo do parque, então existe um espaço adaptado para limpeza de mãos e pés que no final do dia estão totalmente enlameados e cheios de terra. Para as crianças bem pequenininhas, um espaço no parque com chão gramado e um pergolado coberto pela ramagem do pé de maracujá plantado na aula de educação ambiental pretende fazê-las acostumaremse aos poucos com a grama, as pedrinhas e os bichinhos característicos da área verde natural. Com toras de madeira e pneus, a ideia de um carro que se transforma a cada nova brincadeira de cada criança que se aventura a se equilibrar por ali. E nesse carrinho - às vezes um trem, um avião, um navio, um submarino ou um barco -, elas vão para o zoológico, o shopping, a casa da vovó, o parque de diversão ou o clube. Às vezes, é uma loja ou um restaurante em que os maiores vendem seus produtos e alimentos e os menores são ajudados a comprar, comer e beber. Por fim, em um espaço lateral do parque está a estrutura da educação ambiental: galinheiro com um buraco baixinho na cerca para as crianças darem às galinhas, todas com nome próprio, o resto das frutas e verduras do lanche; a horta com todo tipo de plantas e as pegadas das crianças que aprendem a circular entre os canteiros quando vão plantar, regar, preparar a terra ou fazer a colheita; a espiral de ervas com os canteiros de flores onde os mais aventureiros gostam de cheirar e experimentar a erva-doce; o viveiro com os materiais para o início do plantio das mudas e, no cantinho, a composteira para produzir o adubo.

Nesse parque, as crianças ficam todos os dias durante uma hora, e sempre é pouco demais. Todas brincam juntas, independente de sua idade, que vai de um a cinco anos. Elas aprendem a conviver, observam os limites umas das outras, cuidam dos menores e os ajudam a subir em alguns brinquedos. Inventam brincadeiras de correr, observam o formato das nuvens quando deitam na grama, debruçam-se a observar o caminhos que as formigas fazem pela grama e os casulos das borboletas e cigarras, desafiam-se a carregar uma minhoca ou uma lagarta - sob o olhar e cuidado de todas as educadoras, que se revezam e brincam com todas as crianças de todas as turmas. Quando uma educadora passa de uma turma para a outra, no parque acabam com a saudade e brincam juntas. Joelhos ralados, pés cheios de terra, água fresquinha para beber fazem parte da rotina, e todas correm felizes e livres pelo gramado.

Nas salas e nos ambientes internos, a simplicidade é o pilar. Nada de muitos brinquedos, emborrachados ou imagens que sobrecarregam. Nas paredes só os desenhos, as pinturas e o calendário dos aniversários das crianças. Uma sapateira no lado de fora da porta na altura das crianças (da turma de um a cinco anos) para que elas possam guardar seus sapatos sozinhas quando chegam. Ganchos para as mochilas ficam dentro da sala, perto das mesas do lanche. Em um tapete no centro da sala elas brincam juntas. E descansam num colchão com almofadas em um canto da sala. Um trocador com os materiais de higiene e uma prateleira com os copos para beber água. No outro canto, a casinha. Toda de madeira com um pano para a cobrir à guisa de telhado, um fogão com pia e panelinhas com frutas e verduras de pano. Para brincar, ainda dois caixotes de madeira com livros e bolas de pano ou plástico, bonecas de pano, bercinhos, paninhos e alguns brinquedos de encaixe.

Nas atividades internas, as crianças exploram as artes com tinta guache, giz de cera, barbantes coloridos, colas coloridas, papéis de diversas texturas fazendo colagens individuais e coletivas, pinturas com pincéis e com as mãos. Brincam de massinha modelando o que quiserem; minhocas, bolinhas, comidinhas, casas da sua imaginação e bichinhos. Constroem brinquedos e objetos com materiais reciclados que às vezes levam para casa, outras brincam na escola e outras continuam nas aulas de educação ambiental.

Aprendem a cuidar de todos os brinquedos e móveis da sala e de uso pessoal no Projeto do Cuidar, quando participam de atividades com paninhos e esponjas para limpar a sala e todos os dias cantam uma música para ajudar a guardar e organizar a sala, coletivamente. Compartilham momentos de leitura com os livros do Projeto do Livro Amigo em que semanalmente cada criança leva um livro de um amigo para casa e lê com sua família, trazendo-o na semana seguinte e trocando com outro amigo. Também aprendem a brincar juntas com o Projeto do Dia do Brinquedo (a segunda-feira), quando trazem de casa um brinquedo escolhido para brincar juntos em sala - um baita desafio! 
A musicalização atravessa todas as atividades da escola, desde o acolhimento no início da manhã ou da tarde; a organização da sala e dos brinquedos; o momento de lavar as mãos para lanchar; o lanche; a saída para o parque e o retorno para a sala com o fechamento do dia. Mais do que acompanhar e guiar a rotina, a música é trabalhada mediante criações das educadoras que constroem canções simples e gestuais assim como cantam músicas que recordam a infância de cada uma e aquelas que são cantadas nas casas das crianças.

O Projeto MusiMultidisciplinar desenvolvido em parceria com o Grupo Sementes - Música e Terapia traz para as crianças aulas de musicalização - elas dançam livremente, tocam instrumentos, imitam gestos e sons, criam sons - e aulas de circo, teatro, contação de história e inglês a partir da música. A proposta é ter todas essas atividades por meio da música, feitas com música. As aulas de capoeira e de danças de raízes afro-brasileiras para as crianças de três a cinco anos agita a criançada! Elas fazem piruetas, cambalhotas, atividades de psicomotricidade, aprendem a gingar, exploram e escutam o som do berimbau, imitam os animais com diversas posições que depois viram belas gingas da roda de capoeira.

E nas aulas de culinária todas as crianças colocam a mão na massa fazendo pães, bolos e pizzas integrais. São receitas que as famílias fazem em casa, geralmente, herdadas de caderninhos de avós e bisavós. Elas experimentam cada ingrediente, cheiros, texturas, gostos, dividem-se nas tarefas da receita, sovam a massa e colocam as bolinhas para assar. Depois, deliciamse com os quitutes e, quando sobra, levam para casa. Os pais e as mães sempre pedem para levar mais.

\section{Revisão de Literatura}

Ensinamos e não sabemos o que quer dizer ensinar. Por isso perguntamos sobre o que significa ensinar. Também por isso, como ensinantes, nos perguntamos sobre o significado de ensinar. No mesmo movimento, perguntamos e somos perguntados sobre o significado e o sentido do que fazemos quando ensinamos (Kohan, 2005, p.185).

Refletindo filosoficamente sobre a tarefa de ensinar segundo a perspectiva compreendida nessa pesquisa não cabe como objetivo determinar quais subjetividades propriamente ditas serão construídas nem afirmar que um modo ou outro de educação - e de construção simbólica - é melhor. Compreendemos que

Somos seres históricos, que nos construímos na cultura e na concretude das relações sociais. E, como a história, a cultura e a sociedade em que nos constituímos como humanos estão, elas mesmas, em constante processo de construção e reconstrução, graças a nós mesmos, que as modificamos, o contexto humano é um terreno movediço, marcado pela transformação, por graus de incerteza, de incompletude (Pulino, 2016a, p.49).

O intuito, portanto, pelo contrário, é apenas levantar questionamentos verdadeiros a respeito de puras inquietações que aparecem no processo de construção de um espaço que considera e valoriza o brincar livre, o conhecimento por meio da conscientização ambiental, práticas de liberdade e autonomia, temporalidades não rígidas ou individualizantes, as artes como meio de aprender e a experiência de ser com o outro - seja ele uma criança, um bebê ou um adulto.

Quando nos colocamos em uma posição de perguntar por que, como e para que estamos realizando determinada atividade, nos deparamos com significativas provocações filosóficas a questionar - inquietudes pessoais que desvelem nosso próprio “eu” enquanto as enfrentamos, uma vez que, para fazer a pergunta do outro, necessitaríamos ser o outro. Sendo assim, o espaço coletivo está todo imbricado de "por ques", "para ques" e "comos" de diversos sujeitos. Quando esse espaço de que estamos falando é o da escola, deve-se pensar em muito mais do que formação intencional de pessoas.

A intencionalidade formadora da escola tem sido reconhecida de forma crescente: os profissionais de educação afirmam, de forma explícita, que se interessam, sobretudo, pela "formação" de seus visitantes; que a escola se propõe não só, ou não especificamente, transmitir conhecimentos, mas antes que outras coisas, formar pessoas, produzir certos tipos de subjetividades (Kohan, 2005, p.77). 
Isso porque cada sujeito envolvido é singular em sua forma de ser, e o processo acontece quando se juntam todas as singularidades para criar um outro "quase sujeito".

Partindo do princípio de que a educação pode contribuir com a construção de sujeitos, cabe colocar o "princípio da transformação" (Larrosa, 2016a), segundo o qual a experiência forma e transforma o homem, por si mesma e também por sua capacidade de estar em transformação.

A disposição do espaço, as formas meticulosas de regular a vida interna da instituição, a distribuição de pessoas e funções constituem um bloco compacto de capacidade-comunicação-poder. Nas escolas, os indivíduos não fazem qualquer coisa, em qualquer momento, em qualquer lugar. Os espaços são cuidadosamente delimitados, o tempo é marcado por um cronograma preciso, regular e regulado, os aprendizados são organizados em etapas, de forma tal a exercitar em cada período, um tipo de habilidade específica (Kohan, 2005, p.79).

Desse modo, para a constituição de sujeitos capazes de autonomia, solidariedade e responsabilidade, a educação precisa ser construída de forma a permitir que o sejam. Praticando um ensino tecnicista, conteudista priorizam-se algumas questões; e, quando se propõe o contato com outras ferramentas e modos de ensinar, procuram-se outras formas de constituir o sujeito, tanto o que aprende quanto o que ensina.

Edgar Morin (2011) aponta sete saberes necessários à educação do futuro que podem orientar as reflexões propostas. O primeiro deles refere-se aos erros e ilusões do conhecimento, mantendo o habitual processo de conhecimento, que entende o homem estático, em vez de considerar os funcionamentos que o constituem, como características cerebrais, mentais, culturais e psíquicas. O segundo seria a educação do conjunto, dos complexos em vez das divisões em diversas áreas e disciplinas, um conhecimento fragmentado que se junta em partes. Propõe-se construí-lo em seu conjunto completo. O terceiro refere-se a ensinar a condição humana entendendo o homem como, a um só tempo, físico, biológico, psíquico, cultural, social e histórico, sendo necessária a compreensão dessa condição para entender as identidades individuais e coletivas. O quarto relaciona-se à condição terrena, que toda a população mundial vive em seu contexto desigual, a fim de fazer entender que todos vivem sob uma mesma condição de existência. O quinto ensina o lugar da incerteza diante de todas as certezas que as ciências físicas, as ciências da evolução biológica e as ciências históricas nos trouxeram e trazem. O sexto ponto diz respeito a ensinar a compreensão entre todos e, para que seja possível, a reinvenção das mentalidades. O sétimo trata da ética do gênero humano com relação ao tripé que cada ser humano constitui enquanto indivíduo, espécie e sociedade, valorizando a democracia e a sociedade como comunidade planetária (Morin, 2011, p.15-18).

Ainda nesse sentido, é necessário pensar qual caminho a escola quer trilhar para, como em todo caminho, chegar em algum lugar. Assim, quais subjetividades pretendemos construir? Onde e por que optamos por determinadas atividades? Por que ter aulas de educação ambiental? Por que a prioridade em espaços afastados da cidade, em ambientes mais naturais?

Segundo Larrosa (2016a), a experiência enquanto forma de ser e estar no mundo é algo que se passa com os indivíduos, e o sujeito da experiência se permite passar por alguma situação - não em sentido de alienação ou falta de ação, mas de se deixar viver, ter experiência. São sujeitos da experiência aqueles que estão abertos a deixar que se transformem e formem, sejam construídos e reconstruídos, posto que a experiência é sempre imprevisível e requer ausência de pré-saberes ou determinações diante de algo.

A escola se faz em espaços de experiências. Todos os dias crianças e professores estão vivenciando esse ambiente. Nesse sentido, Pulino (2012b, p.184) questiona o que é educar e logo aponta o que aqui se quer repensar: “Certamente, não é um processo que se aplique a todas as pessoas, de forma padronizada. Nem que se aplique sempre da mesma maneira para a mesma pessoa".

Pensar essas vivências a partir da experiência, entretanto, não é só observar o meio escolar; é preciso permitir espaços de construção da experiência ou simplesmente permitir que a experiência o seja, como se pode refletir e, segundo o que afirma 
Benjamin (1994, 1995), compreender os espaços e a temporalidade da infância em um processo de contínua transformação e visão de mundo que se transfigura por um olhar de descoberta, simplicidade, de encantamento e conhecimento por meio das linguagens narrativas.

Consequentemente, pensar as rotinas e os planejamentos das atividades não pode ser algo desligado do restante da proposta pedagógica. Sendo assim, os educadores precisam estar atentos ao espaço que a experiência necessita para existir, às nuanças das expressões das crianças e a um movimento de autoeducação para desconstruir-se diante de práticas que trazem outro tempo escolar, que não o tempo da experiência.

A temporalidade da escola tem sido quantitativa, descartando-se o aspecto qualitativo; nela não há espaço para deixar acontecer, para considerar pressuposições. As crianças têm sempre que estar seguindo a constância dos conteúdos que lhes são passados - passados, aliás, já prontos, pensados para atividades e tarefas que não deem margem às respostas das crianças, mas apenas às respostas que os professores querem das crianças. E isso as crianças percebem. Assim, segundo Benjamin (2002), o que se apresenta na escola é uma vivência. A experiência não está relacionada com a informação; a vivência está. A experiência requer um mistério e outra duração; a vivência é fragmento, objeto. A experiência percorre o âmbito do tempo qualitativo; a vivência só existe no tempo quantitativo. As escolas, em sua maioria, não têm tempo de ensinar a partir de uma relação dialógica com o conhecimento; ministram suas aulas de forma mecanizada; ensinam a seus alunos como se sempre estivessem atrasadas para “dar” o conteúdo do próximo capítulo do livro didático.

Assim, as mudanças trazidas pela modernidade, de acordo com Benjamin (1995) suscitaram diversas consequências para a construção da sociedade, do mundo e de como os homens se relacionam uns com os outros, com o exterior e consigo mesmos. A história, que se pode dizer ser um objeto de estudo desse teórico, entrelaça concepções e leva a transformações diferentes conforme a perspectiva por que é considerada. A questão da temporalidade se faz presente no pensamento linear e cronológico, e, consequentemente, vazio da historiografia burguesa e da historiografia progressista, predominantes no advento da modernidade.

Mesmo que não seja possível conceituar a experiência de acordo com o autor, visto que ao longo de toda a sua obra a experiência vai-se compondo e se decompondo, é possível afirmar que a experiência (Erfahrung, em alemão) se transforma, entre outros pontos, nessa nova relação da história e de seus desmembramentos para com outras questões que desvela. Na realidade, a modernidade caracteriza-se pelo declínio da experiência, possibilitando apenas a vivência (Erlebnis).

Benjamin retoma a questão da "Experiência", agora dentro de uma nova problemática: de um lado, demonstra o enfraquecimento da "Erfahrung" no mundo capitalista moderno em detrimento de um outro conceito, a "Erlebnis", experiência vivida, característica do indivíduo solitário; esboça, ao mesmo tempo, uma reflexão sobre a necessidade de sua reconstrução para garantir uma memória e uma palavra comuns, malgrado a desagregação e o esfacelamento do social (Gagnebin, 2004, p.9).

Outro ponto a ressaltar nos estudos desse autor é sua relação com a narração. Estaria aqui uma questão fundamental para compreender o declínio da experiência com as mudanças do século XIX, pois é com a substituição dos contos, histórias, lendas e formas antigas da experiência de contar por meio da informação e do romance que a Erfahrung dá lugar à Erlebins, e somente a ela.

O que nos interessa aqui, em primeiro lugar, é o laço que Benjamin estabelece entre o fracasso da "Erfahrung" e o fim da arte de contar, ou, dito de outra maneira inversa (mas não explicitada em Benjamin), a ideia de que uma reconstrução da "Erfahrung" deveria ser acompanhada de uma nova forma de narratividade (Gagnebin, 2004, p.9).

Por que, entretanto, não seria mais possível a experiência em sua forma original? Por que, para o homem moderno, só seria possível a vivência? O declínio da experiência vem com o tempo quantificado, rápido, veloz e sempre igual, tal como o que 
o capitalismo instala no mundo. Não seria mais possível contemplar, partilhar ou nem sequer construir experiências. As teorias do progresso e a vida passam a se basear na busca incessante do futuro. O passado deve ser superado, esquecido, ignorado em um presente que vive em prol do futuro. O que vai ser produzido, alcançado, construído no futuro é o grande objetivo da vida dos homens. O que pertence ao passado não faz mais sentido, e a própria vida não teria razão de ser não fosse pelo que cada um vai fazer no presente visando ao futuro.

A maneira de contar a história da humanidade também se modifica, como tantos outros aspectos do cotidiano - as escolas, as paisagens, as brincadeiras, o trabalho -, e com essa mudança surgem os grandes interesses e alicerces da palavra que guia o mundo moderno: a informação - com seus excessos e bombardeios - e a valorização dos romances, seja nos livros, nas histórias, nas novelas, nas relações humanas. Com isso, a sociedade e os homens vão-se constituindo de outras formas, e disso o espaço escolar não está livre; é possível e provável perceber tanto a inexistência de experiência, tal como proposta por Benjamin (1995), nas práticas escolares quanto a precariedade da narração.

E o que seria essa narração na modernidade? O que Benjamin caracteriza pela ignorância da arte de contar? Ignorância aqui usada não só no sentido de desconhecer a importância de algo, mas também compreendida pela falta de conhecimento do que seja a arte de contar, visto que hoje lidamos com as vivências e não mais com experiências. De acordo com Benjamin (apud Gagnebin, 2004), as condições para a falta do saber contar se devem, primeiramente, ao caráter comum que a contação demanda, ao desrespeito à noção de comunidade entre os indivíduos, o que o capitalismo rejeita sem ressalvas, e ao distanciamento entre as pessoas, o que as torna frias e individualistas. O primeiro e o segundo aspectos estão vinculados, visto que a prática artesanal dá lugar à produção em série, mecanizada e técnica. Que relação teria o artesanato com o fim da arte de contar? Pois bem, o tempo do artesão configura-se por "um tempo mais global, tempo onde ainda se tinha, justamente, tempo para contar" (Gagnebin, 2004, p.11); além disso, o artesão, na arte de seu ofício, não agride a matéria utilizada; pelo contrário, ela se transforma em produto em constante diálogo com o artista que a manipula, permitindo que ele a modifique e lhe dê nova forma. Exatamente como os velhos, antigamente, contavam suas histórias aos mais jovens a fim de simplesmente dar continuidade ao que desejavam partilhar, repassando-lhes ensinamentos e explicações profundas sem, no entanto, apontar caminhos ou conclusões. Este ensaio pauta-se na narrativa da pesquisadora diante do que foi vivido. Assim, traz reflexão em tempo do que foi aprendido, vivenciado. Mesmo que não tenha sido experiência, do ponto de vista de Benjamin (apud Gagnebin, 2004), pois essa não seria possível em tempos que se seguiram às mudanças da modernidade, este trabalho tem o caráter das narrativas às quais ele se refere, visto que, assim como com o fazer do artesão, o que é narrado aqui o é por meio do que foi vivido e modifica-se em nova maneira de ser visto, interpretado, refletido, enfim, em “tempo para contar".

A preciosidade do tempo qualitativo está justamente em permitir às crianças que se constituam não de forma almejada pelos adultos ou predefinida, mas agindo como os artesãos faziam: transformando sua matéria - o conhecimento - em um constante, mas nada contínuo, trabalho de respeito e reconstruções de um eterno saber que se modifica em meio a uma dança entre o contato com o mundo, os outros e suas próprias ideias. Saber que, se posto em relação com o acontecimento lembrado por Benjamin (apud Mitrovitch, 2007), não é finito e depende de ligações feitas pelo indivíduo para que se torne memorável, constituído em conhecimento.

O tempo-do-agora é o momento do despertar: despertar no presente esse sonho que se chama passado é a tarefa da experiência. Uma tarefa, segundo Benjamin, profundamente coletiva, a qual depende do irromper da consciência desperta, ou seja, depende da Erlebnis, mas tem como prioridade a transformação (Mitrovitch, 2007, p.86).

Estaria nesse tempo-do-agora a possibilidade de escape a uma vivência pautada no tempo quantitativo, reprodutivista, moderno. Estaria presente, portanto, a possibilidade de fazer experiência e viabilizar intensos e únicos momentos de resgatar a experiência perdida com as mudanças introduzidas pelo século XIX. 
Transpondo para um trabalho realizado com as crianças, seria, portanto, preciso e necessário resgatar exatamente esse tempo-do-agora ao qual Benjamin (apud Mitrovitch, 2007) se refere, pois é possibilitando o diálogo com o processo de construção do conhecimento, o tempo qualitativo, a narrativa, como ele coloca, e, talvez mais explicitamente, comparando com o trabalho do artesão que as crianças poderiam reconstruir suas ideias e ser participantes do processo de aprendizagem a que a instituição escolar tanto se propõe.

Utilizando as palavras de Larrosa (2008, p.193), “A temporalidade da espera, no entanto, é uma temporalidade aberta: não é antecipação, mas atenção, disponibilidade, escuta, a única forma de temporalidade em que o inesperado pode acontecer". Estaria nessa temporalidade da espera, a possiblidade de construir novas formas de educação, de relação com o outro - incluídas as crianças - para que o novo pudesse acontecer nas escolas, permitindo reinventar espaços e criar lugar para viver a experiência com outras subjetividades.

É comum ouvir relatos de educadores colocando os diversos papéis que desempenham em seu cotidiano. Eles têm funções de professores, terapeutas, mães, pais, familiares, amigos, babás... e a lista vai se alongando. No cerne dessa questão está o verdadeiro papel do educador - mas qual seria ele na sociedade contemporânea e em uma proposta de espaço escolar inovador?

Primeiramente, há que pensar sobre aprendizagem. E Pulino (2016a, p. 55-56) elucida a compreensão que geralmente temos acerca do que é a aprendizagem escolar: "Como processo de construção de conhecimento, que se dá na escola a partir do encontro de educadores e alunos, que entram em contato com a produção de gerações passadas (...)”. Mas por que é importante pensar nesta concepção - a da aprendizagem - quando estamos falando sobre o papel do professor? Simplesmente porque a postura, os valores, o olhar, as exigências, as atividades e todo o restante que envolve o trabalho docente estará partindo de sua concepção de aprendizado, quem é seu aluno, como ele enxerga essa relação e o que acredita ser seu trabalho.

De acordo com Dias (2009), o emprego tornou-se algo exclusivamente focalizado na produção, proporcionando, assim, desenvolvimento ético, reconhecimento social e posição de destaque na sociedade. Essa concepção de trabalho, entretanto, muitas vezes, distancia o homem de relações mais humanas e o coloca em um sistema de competição em que é preciso estar sempre ganhando do outro, pouco se importando com esse trabalho em conjunto para o bem comum.

A visão proposta, contudo, é de que o professor não seja o dono do conhecimento, tendo como tarefa expor o que já está pronto e dado. A proposta que cabe nessa perspectiva é, como Pulino (2016a) aponta, a de que o professor esteja em conjunto com seus alunos construindo e reconstruindo o conhecimento de gerações anteriores, trabalhando com valores, ideias, práticas e costumes.

Quando falamos sobre um espaço escolar inovador, esvaem-se as funções tradicionais de um professor - planejar sua aula, transmitir o conteúdo aos alunos, avaliá-los em dias predeterminados e entregar boletins no final do ano. É preciso compreender que outras demandas surgirão, que outro tempo será proposto, entre tantas outras questões, que o professor precisa saber trabalhar com coletividade, improvisos e reconstruções. E nenhuma dessas características se aprende na formação docente.

No exercício das tarefas de educar e cuidar, todos desempenham funções de igual importância e assim são reconhecidos por toda a comunidade escolar. O controle do que está sendo feito também é responsabilidade daqueles que fazem, porque estão todos envolvidos nas atividades da escola e se beneficiam do trabalho em conjunto; caso alguém deixe de se empenhar, todo o trabalho fica comprometido, visto que tanto os ganhos quanto as perdas afetam todo aquele coletivo. De acordo com Althusser (1985), a escola é um aparelho ideológico do Estado que, de alguma maneira, acaba por criar sujeitos que condizem com aquilo em que a escola acredita. Dessa forma, pode-se perceber que, devido a diversos mecanismos que possam vir a ser criados dentro de um espaço escolar inovador, há a preocupação de construir com os alunos uma escola que mostre conceitos como solidariedade, responsabilidade, respeito e trabalho em equipe. 
"Na sociedade moderna, capitalista, as relações deixam de ser naturais para serem dominantemente sociais. Neste sentido é que a sociedade capitalista rompe com a ideia de comunidade para trazer, com toda a força, a ideia de sociedade" (Saviani, 1999, p.155). Tradicionalmente, as escolas refletem o que a sociedade é e a maneira pela qual ela se percebe. Em ambiente escolar que acredita em outras questões e trabalha com proposta pedagógica diferente de uma lógica que reflete o sistema capitalista, o sujeito pode ser concebido de outra maneira e percebe-se que existe sempre uma luta em preservar aquele espaço organizado em comunidade. E mesmo nesse meio de cooperação as diferenças aparecem e outros problemas surgem, demandando que o trabalho e o engajamento estejam sempre se renovando e sendo repensados. Também se evidenciam as percepções sobre esses aparelhos repressores e ideológicos quando interagimos em outros espaços, porque uma vez que se adapte a uma visão crítica, participativa e criadora, o comportamento daí decorrente há de manifestar-se em todos os momentos nas mais diferentes situações. Não é, contudo, fácil a tarefa de estar atento aos acontecimentos e posições tomadas, questionando-os permanentemente, embora seja extremamente importante para a compreensão do mundo e das formas como ele se organiza e faz com que o homem viva de determinado jeito, já que influencia diretamente aspectos do próprio sujeito. Ir de encontro àquilo que já estamos acostumados a realizar, rotineiramente, é, portanto, uma tarefa árdua, mas dá-nos esperança, pois que, "reeducar nosso olhar, nossa sensibilidade para com os educandos e as educandas pode ser de extrema relevância na formação de um docenteeducador" (Arroyo, 2012, p.62).

Tratando-se de um espaço escolar para crianças ainda na primeira infância, as tarefas de cuidar e de educar são dois importantes eixos de trabalho. Nem a uma, nem a outra deve-se dar destaque, posto que é necessário desempenhar as duas e em ambas encontrar seu lugar como educador. Nesse sentido, a Pedagogia Waldorf traz como essencial nessa fase de desenvolvimento da criança - entendida como um ser humano cuja educação demanda um olhar holístico - a ilustre tarefa de ensinar que o mundo é bom trabalhando no âmbito de três sentidos: o sentir, o querer e o pensar. Sendo assim, o cuidado com suas necessidades básicas, a atenção às demandas e a escuta são fundamentais para quem lida com a educação infantil, assim como a preocupação com as atividades e os espaços que serão oferecidos à criança, bem como com seu planejamento.

Valendo-me aqui do que traz Larrosa (1999, p.51), "essa é uma bela imagem para um professor: alguém que conduz alguém até si mesmo”. Em um contexto de cooperação para estabelecer as relações entre educadores, crianças e suas famílias, fica evidente a necessidade de conceber a tarefa de educar não pelo viés exclusivo - da técnica e da metodologia -, mas por uma formação que vai além e edifica o sujeito a tornar-se digno dessa tarefa de educador, encontrando espaço para o educando em sua alteridade, liberdade, necessidade de ser cuidado e amado por seu professor.

Miguel Arroyo (2012) conduz-nos em um bela direção quanto à forma como devemos lidar com o aluno e conosco para que possamos enxergar a criança que está diante de nós assim como nos redescobrir também. Sobre essa questão, aponta que "as autoimagens docentes nos levaram a construir e manter determinadas imagens de alunos(as). Os confrontos sobre se os olhamos e como os olhamos refletem como nos olhamos" (p.54). Dessa forma, devemos estar atentos aos planejamentos e questões pedagógicas quando estamos dentro de sala de aula ou em uma escola, mas é preciso aprofundar o conhecimento sobre nossa essência, nossas subjetividades, nossos papéis, sobre os valores, hábitos e costumes que adotamos nos ambientes em que escolhemos viver. A maneira como nos compreendemos - ou não - educa nosso olhar sobre a criança e, com esse olhar educado, direciona nossas ações e falas, nossos silêncios e sentimentos sobre a relação que construímos com alunos e alunas e com nosso trabalho de educar e cuidar deles, delas e de nós, já que "a maneira como os enxergamos pode ser determinante da maneira como lhes ensinamos e os educamos. Pode ser determinante da maneira como vemos nossa humana docência (p.62).

Tratando-se de crianças pequenas - mas, principalmente, de seres humanos - devemos estar comprometidos e não mais ignorar as maneiras como organizamos nossa sociedade, nossas escolas, nossos espaço de convivência. Existem, hoje, diversos lugares que investem em outras formas de educar, procurando modificar olhares e repensar saberes. Estaríamos caminhando para uma reinvenção da pedagogia? De nosso modo de viver? 
Humanizando nosso olhar docente poderemos estar reeducando o prazer, a alegria, a sensibilidade, a imaginação, a interrogação... potencialidades que entram em jogo quando o foco da mirada humana são crianças, adolescentes, jovens ou adultos. A mirada humana sobre os educandos(as) poderia ser humanizadora da docência (Arroyo, 2012, p.65).

As crianças da educação infantil estão na escola, na maioria das vezes, porque seus pais precisam de um espaço que as acolha porque estão trabalhando. Elas, por sua vez, precisam de amor, de carinho, de atenção. Precisam do aconchego e acolhimento da professora ou do professor. Assim como precisam dar vazão a seu desejo de descobrir e explorar, e fazê-lo em atividades que trabalhem com artes, música, corporeidade, natureza e diversos outros elementos. Não se está tirando a importância da aprendizagem e do estímulo. Apenas não é necessário nos deixar tolher e limitar nem os limitar e tolher. A vida não é feita disso. Tampouco a escola precisa ser. Logo,

Estamos caminhando para alguns consensos: que é urgente conhecer melhor os alunos; que olhares negativos, preconcebidos e preconceituosos não nos permitem entender-nos; que é necessário conhecer suas trajetórias escolares para além dos clássicos boletins e registros de notas, conceitos, aprovados ou reprovados; que sem conhecer suas trajetórias humanas não conheceremos suas trajetórias escolares (Arroyo, 2012, p.81).

Existe muito mais em uma sala de aula do que simplesmente conhecimentos sendo construídos e compartilhados. As escolas são plenas de diversidade, oferecem a convivência diária de crianças e adultos com infinitas possibilidades de ser, de falar, de se comportar. Misturam-se costumes, hábitos, valores, crenças, opiniões. São tantos os processos de desenvolvimento que acontecem em pequenas relações e interações entre os pares envolvidos, que o educador precisa ter elucidado o valor de seu trabalho. Deixar-se envolver pela sobrecarga de tarefas - problema que advém de diversos motivos, mas que também pode ser resolvido no diálogo coletivo - ou pelo acúmulo de ações que o cuidado com a criança pequena demanda pode ser, às vezes, mais fácil e automático. Se, porém, existe a oportunidade de tomar pelas próprias mãos a nobreza que tem um profissional da educação infantil... não há dúvidas de que é possível criar e recriar condições plenas de vida, de crescimento, de aprendizagem, de desenvolvimento humano respeitado.

Para tanto, o educador deve questionar-se, se reinventar, sair da conformidade e colocar-se à prova também. Infelizmente, "resolvemos por nossa conta reduzir a função que a sociedade nos delegou de socializar, formar e acompanhar o desenvolvimento pleno dos educandos, apenas a informar, instruir suas mentes” (Arroyo, 2012, p.129). Se não são impossíveis, as mudanças também não acontecem de um dia para o outro, e, antes de tudo, é preciso nos certificar de que estamos realmente olhando para essa questão.

Ensinar é participar dos processos de construção do conhecimento do aluno. O trabalho do professor deve dirigir e orientar o planejamento na realização das aulas e das atividades curriculares, além de avaliar o processo de conhecimento do aluno com base em determinados propósitos, em conteúdos específicos e em modos adequados para conseguir alcançar seus objetivos.

Ser professor significa mais do que ser um mediador entre o aluno e o saber constituído socialmente. Ser professor é ser um sujeito ativo do processo da construção do saber, ao mesmo tempo em que está em formação e formando a personalidade dos seus alunos (Pedroza, 2012, p.227).

Nesse processo de ensino, considerado socioconstrutivista, o aluno é ativo porque ele é o sujeito do processo, e, por isso, sua atividade mental ou física é fundamental para a relação dinâmica com os objetos do conhecimento; e o professor é ativo porque é ele quem faz a mediação entre o aluno e aqueles objetos. Nesse sentido, o saber elaborado só é objeto do conhecimento se for questionado, confrontado com outros entendimentos, incluindo-se o entendimento do próprio sujeito. 
O intuito deste trabalho é reforçar alguns aspectos de análise desses pontos e acrescentar outros a fim de extrair suas implicações para uma metodologia centrada no princípio orientador básico da necessidade de confrontar as representações sociais dos alunos e os conceitos científicos a ensinar.

A construção de conceitos é habilidade fundamental para a vida cotidiana, uma vez que possibilita à pessoa organizar a realidade, estabelecer classes de objetos e trocar experiências com o outro. E para compreender esse processo de construção do conceito é preciso prestar atenção em conceitos do socioconstrutivismo. Assim, as funções mentais superiores do homem (percepção, memória e pensamento) desenvolvem-se na sua relação com o meio sociocultural, relação essa que é mediada por signos.

$\mathrm{Na}$ relação do homem com o mundo ocorrem dois processos que cabe destacar em função de suas implicações educacionais: o processo de ensino e o desenvolvimento. Segundo Vygotsky (1991) a aprendizagem escolar pode puxar o desenvolvimento e fazer com que ele ocorra antecipadamente. O autor, entretanto, enfatiza o conceito de zona de desenvolvimento proximal, com o intuito de trabalhar com funções e processos ainda não amadurecidos pelos alunos, munindo o professor de um instrumento significativo na melhoria da qualidade de suas aulas, no tocante ao desenvolvimento intelectual dos alunos, e, em consequência, propiciando melhores condições de aprendizagem efetiva.

As possibilidades do desenvolvimento do pensamento na escola, pela escola, dependem em boa parte da qualidade dos instrumentos mediadores, destacando-se, dentre eles, a fala. Faz-se então presente a relevância da mediação do professor em uma relação dialógica de ensino. Conforme foi assinalado, na sua relação cognitiva com o mundo, o homem exerce uma atividade mediada por instrumentos e signos, e com eles, então, opera material e racionalmente o mundo, podendo, portanto, compreender sua realidade e estar em constante construção e transformação de seu meio.

A internalização consiste nas seguintes transformações: de uma atividade externa para uma atividade interna e de um processo interpessoal para um processo intrapessoal. Essas transformações são fundamentais para o processo de desenvolvimento de funções psicológicas superiores e interessam particularmente ao contexto escolar porque lidam com formas culturais que precisam ser internalizadas pelo sujeito. Na internalização há um processo de transformação, de modificação da compreensão individual, há uma reorganização individual em oposição a uma transmissão automática dos instrumentos fornecidos pela cultura.

O professor e os amigos da turma são referência do outro, do social, assim como é a cultura socialmente elaborada. Todos são importantes para a construção do conhecimento de cada indivíduo. Logo, o desenvolvimento psicológico deve ser considerado de maneira prospectiva, isto é, para além do momento atual; os processos de aprendizagem movimentam os processos de desenvolvimento, a cultua e o indivíduo, bem como a promoção dos processos interpsicológicos que serão posteriormente internalizados.

Da mesma forma, o conceito de lugar deve ser construído pelo aluno a partir dos valores e atitudes praticados na vivência cotidiana em seu bairro e deve resultar em reavaliações de uma ética ambiental. O trabalho com os mapas mentais tem por finalidade conhecer o nível de consciência espacial, ou seja, entender como os alunos percebem o lugar em que vivem.

Uma criança, como, aliás, em geral qualquer indivíduo, é capaz de fazer mais com o auxílio de outra pessoa do que faria sozinha. Sendo assim, as atividades de aprendizagem programadas pelo professor não devem requerer apenas as capacidades e habilidades presentes no aluno, mas devem pautar-se pelas possibilidades futuras, potencializadas com o trabalho de cooperação. As atividades de cooperação entre os alunos são importantes para o processo de socialização, para o desenvolvimento e, logo, para a aprendizagem.

Evidencia-se o fato de que a maioria das escolas dispõe de mecanismos que individualizam as crianças - avaliações, atividades em sala de aula, distribuição de tarefas pelo professor, entre outros. Então, quando aparece um trabalho em que as crianças precisam unir-se para realizar, elas estranham. Adaptaram-se a ter sempre alguém que lhes dê ordens e, mais, aprenderam a relacionar-se de forma individual. Convivem diariamente em um mesmo ambiente, mas distantes da coletividade, 
da autonomia e do exercício da liberdade. Pensar um ambiente coletivo acarreta pensar pessoas trabalhando em conjunto e, sobretudo, a questão da autonomia.

É, essencialmente, com os pais e os professores que a criança encontra os limites de um controle que lhe permite progredir numa autonomia, que é liberdade de experiência e de expressão dentro de um sistema de relações e de trocas sociais. Conclusão: a autonomia convive com a solidariedade (Pacheco, 2012, p.3).

Paulo Freire (2007) aponta características da consciência ingênua e da consciência crítica que ajuda a pensar como os sujeitos envolvidos em um mesmo propósito devem estar sempre atentos à maneira como buscam soluções e se apresentam uns diante dos outros para a resolução dos conflitos que, naturalmente, pelo próprio processo de mudança, se fazem presentes. Cultivar a consciência crítica é talvez um desafio, posto que pode significar o êxito ou o fracasso, visto que é com essa forma de ser e conviver que se entende a realidade como mutável e se traz para si a responsabilidade pelos atos e acontecimentos, sem a transferir para o outro e o culpabilizar - e ainda, como princípio, fazendo a relação de diálogo extremamente essencial dentro de um processo de funções e objetivos coletivos.

Segundo Freire (2011), o opressor impõe ao oprimido uma forma de pensar e, logo, de compreender o mundo. Assim, para que a opressão deixe de se exercer nos oprimidos, sua sombra teria que ser expulsa e substituída pela autonomia, processo, entretanto, que não é simples nem de fácil realização. “Os oprimidos, contudo, acomodados e adaptados, 'imersos’ na própria engrenagem da estrutura dominadora, temem a liberdade, enquanto não se sentem capazes de correr o risco de assumi-la" (p.47).

Assim, transgredir uma condição opressora passa pelo medo da liberdade e pelo desafio de expulsar essa condição de opressão. A liberdade, contudo, não é algo externo ao sujeito. Ela lhe pertence, mas é necessário encontrá-la e ter consciência de seu ambiente. É preciso buscar a liberdade e estar constantemente nessa busca.

Nesse processo, existem, naturalmente, problemas. Uma das questões é a dualidade, ou seja, descobrir que não é possível realmente ser se não for livre. Para ser livre é preciso libertar-se de ser oprimido. Logo, sentir-se confortável em seu mundo já não é considerável, pois essa situação deve transformar-se em um mundo de limitações e provocar o surgimento da crença de que é preciso transformar a própria realidade para a superar.

Compreender-se em sua realidade e comprometer-se a transformá-la tampouco são tarefas de fácil execução. Na estrutura oprimido/opressor em que a sociedade, o Estado e, portanto, as escolas estão definidos, é fundamental que haja o trabalho por uma Pedagogia do Oprimido. E para que esse seja efetuado, primeiramente, o opressor precisa estar envolvido e empenhado em mudar sua realidade de opressão. A ele se segue o processo de mudança do oprimido para a Pedagogia dos Homens, em que a liberdade estará presente e em constante processo. Para tanto, Paulo Freire (2011, p.54) sugere que "Quanto mais as massas populares desvelam a realidade objetiva e desafiadora sobre a qual elas devem incidir sua ação transformadora, tanto mais se 'inserem' nela criticamente”.

Dessa forma, um dos problemas que se opõem à libertação também é o de "inserção crítica" dos oprimidos. A libertação exige deles o compromisso com o que vivem e não somente mera explicação ou debates vazios. O opressor nesse momento tem um papel importante e determinante para essa crítica acontecer ou não, já que, segundo o autor, os opressores não têm interesse em incentivar a mudança do estado de imersão de suas realidades oprimidas.

O opressor, nessa busca da transformação e prática de uma Pedagogia do Oprimido também enfrenta desafios. Um deles se relaciona com o medo da liberdade, embora diferente daquele experimentado pelo oprimido. É o medo de "perder" a sombra do opressor que fica nos oprimidos, possibilitando-lhes novas oportunidades e visões de mundo. Logo,

Descobrir-se na posição de opressor, mesmo que sofra por este fato, não é ainda solidarizar-se com os oprimidos. Solidarizar-se com estes é algo mais que prestar assistência a trinta ou a cem, mantendo-os atados, contudo, à mesma posição de dependência (Freire, 2011, p.49). 
Cabe entender a diferença entre ação humanizada e humanitarista. A primeira realmente pode operar mudanças e romper com a imersão do oprimido em sua condição; a segunda não constitui caminho de libertação, visto que mantém uma relação distante com o opressor. Isso porque "a solidariedade verdadeira com eles está em com eles lutar para a transformação da realidade objetiva que os faz ser este "ser para outro" (Freire, 2011, p.49). A Pedagogia do Homem não pode ser efetivada por opressores, já que isso caracterizaria os oprimidos como objetos da prática humanitarista.

Para além das questões das relações entre opressor e oprimido, Freire (2007) apresenta uma proposta que está inteiramente presente neste trabalho e na proposta do espaço escolar em estudo, que é a de uma comunidade que se transforma em conscientização. Ou seja, a partir da consciência que tomam e da qual se apropriam, seus membros tornam-se capazes de um processo de mudança da sua realidade, processo de que participam ativamente caminhando para a busca de uma educação libertadora, freiriana, que passa pela transformação social e uma implicação política desse grupo para consigo e com o pequeno grupo que começa a se constituir.

Veiga-Neto (2005, p.135) elucida a questão ao afirmar que, "se quisermos que o sujeito desde sempre aí cumpra sua dimensão humana, devemos educá-lo, para que ele possa atingir ou construir sua própria autoconsciência, de modo a reverter aquelas representações distorcidas que o alienavam; só assim ele será capaz de se contrapor efetivamente à opressão e à exclusão e, em consequência, conquistar a sua soberania”. É possível seguir esse raciocínio pensando no conceito da vontade de poder quando se compreende que o poder em si carregado no sujeito não determina que afete apenas o dominante, mas o dominado, que não está excluso a instituições ou ao Estado, mas que faz morada no sujeito e em suas relações e subjetividades, uma vez que alude ao desejo de ação sobre o outro.

Assim, uma vez instaurados num espaço socialmente organizado e sistematizado, ainda que pautado pela liberdade e criatividade - importante não confundir com falta de regras e responsabilidades -, cabe aos sujeitos envolvidos mais um desafio: reconstruir para construir novas maneiras de conceber o que é o trabalho, o que são relações horizontais dentro de uma hierarquia de funções e, principalmente, manter-se verdadeiros no processo de ressignificação das relações de poder e de trabalho tão arraigadas em todos os sujeitos dessa sociedade, sendo necessário para o bom êxito dessa empreitada estar aberto para erros e acertos, tentativas e diálogos.

A liberdade de experiência diz respeito à possibilidade de o indivíduo sentir-se confortável para ser e estar em determinado espaço; para entender-se como sujeito que pode atuar sobre esse ambiente em constante transformação com ele; vendo a construção coletiva como um dos alicerces daquele lugar. Assim, segundo Pacheco (2012, p.2), “Autonomia não é um conceito isolado, nem se define em referência ao seu oposto - define-se na contraditória complementaridade com a dependência, no quadro de uma relação social aberta”. Esse, porém, não é um mecanismo simples, porque não é de qualquer troca que resulta um processo de autonomia. Ela precisa basear-se, substancialmente, em outra forma de enxergar o sujeito, na organização do espaço e de seus agentes transformadores - o que não é o mais comumente observado nas relações hoje valorizadas pelas escolas ou pela sociedade em que estão inseridas.

Sendo assim, o exercício de relacionar-se com o outro é um desafio para muitos. Mesmo que essa frase seja contraditória, visto que uma vez utilizando o verbo "relacionar" apresenta-se um outro de forma intrínseca, simplesmente porque, ao se relacionar, é com um outro objeto ou pessoa que se está agindo, transformando, sendo transformado - mesmo que dessa relação não resulte uma mudança propriamente visível à primeira vista. É um desafio porque, nesse exercício, os sujeitos envolvidos precisam do respeito, da confiança, de uma inteligência intrapessoal e interpessoal. Logo, falar em crises e soluções requer ainda que se pense além dos exemplos formatados em diversas instituições da sociedade capitalista e individualista, como, por exemplo, as escolas - uma vez que esses espaços têm por base a aplicação de metodologias, regras e leis que aparecem prontas, para que sejam apenas cumpridas e validadas. Falando em construções coletivas desse espaço - que é a escola - as discussões 
coletivas agregam públicos com interesses antagônicos quando todos deveriam ser em prol da educação das crianças. Para esse fim, é preciso pensar junto sobre os conceitos de infância, de escolarização, do papel do professor e da família nesse processo.

\section{Metodologia}

Trata-se de pesquisa qualitativa, em que o pesquisador se assume como tendo participação observante (Passos, Kastrup \& Escóssia, 2015), relacionando-se com os sujeitos e os campos de intervenção e de análise. Esse estilo de pesquisa possibilita a produção do conhecimento "acerca da realidade plurideterminada, diferenciada, irregular, interativa e histórica, que representa a subjetividade humana" (González Rey, 1999, p.35).

A pesquisa aqui relatada apoia-se na teoria histórico-cultural de Vygotsky (2007) sobre o desenvolvimento humano, que afirma constituir-se o sujeito nas relações que estabelece com o outro, sendo essas relações sempre mediadas por ferramentas técnicas ou semióticas. E, ainda, que o sujeito é um ser inserido em determinada cultura e assim se constrói em constante transformação e troca com o meio. Nesse processo, quando da gestação de uma criança, os pais criam uma imagem sobre esse sujeito que os vai surpreender quando nascer. Assim, ainda no movimento que perdura em sua vida entre a projeção de sua família, sua singularidade e as relações com o meio em que se modifica e é transformado, sua personalidade se constitui; considera-se, portanto, a importância de o espaço escolar defender o direito daquela criança de ser, de pensar, de repensar, de filosofar - e não só ela, mas todos os envolvidos, em interação, promoverem essa dança constante de refletir sobre sua prática.

Vygotsky (2001) ainda nos traz o entendimento de que na pesquisa não há neutralidade, visto que o pesquisador está imbricado no processo tanto por ser ele que fará todas as escolhas de como olhará para os sujeitos quanto por ser também participante desse processo, já que as informações de pesquisa são construídas junto e ao longo do caminho. Sem esquecer que esse mesmo pesquisador realiza um trabalho interventivo em um espaço social e cultural, transformando-o e sendo transformado.

Ainda nessa perspectiva de Vygotsky (2001), pode-se apontar para o fato - que faz muito sentido nessa pesquisa, uma vez que se trata de uma cartografia - de que ele considera que o acontecimento desenvolve o caminho. Ou seja, por mais que haja hipóteses e trajetórias pré-traçadas, não só é necessário como natural que a pesquisa vá sendo desvelada ao longo de sua realização, fazendo despontar, algumas vezes, novos objetivos, novos olhares e, outras vezes, trazendo de forma diferente aquilo que estava previsto.

A pesquisa que se apresenta é empírica, considerando-se que o pesquisador vai a campo; o trabalho é feito na presença e relação com os sujeitos e campos da própria pesquisa. Envolve, assim, as experiências vividas pelo pesquisador e, principalmente, a prática que ele procura ao dialogar a partir das e com as relações sociais que os sujeitos envolvidos vivem em um processo.

A cartografia, que nos inspira, dá conta de uma pesquisa que se pretende no fazer enquanto processo de experiência em sua construção e seu caminho.

Ela compreende que o pesquisador desenvolve relatos de experiência, dispositivos de construção de informações e aberturas para vivências com os sujeitos da pesquisa, em que se relacionem, e construam coletivamente os caminhos para a pesquisa, de acordo com os problemas e questionamentos emergentes ao longo do processo - um caminho metodológico, portanto, que vai do "saber-fazer ao fazer-saber (Passos \& Barros, 2015, p.18).

Nesse sentido, a escolha do método da cartografia deu-se não só por acompanhar a história da elaboração de todo o processo dessa pesquisa como pesquisadora - por estar envolvida na construção desse espaço escolar - como também por permitir abertura de uma metodologia que reconhece os processos como são: acontecimentos que vão surgindo nas relações que vão sendo construídas. 
São 34 famílias que constroem esse espaço escolar. Delas, sete têm dois filhos e ambos estudam na escola (seis são gêmeos); nove crianças têm irmãos mais velhos que ultrapassam a idade-limite para estar na escola e 18 são filhos únicos. Os pais e as mães são de classe média, moram em bairros do Plano Piloto, Jardim Botânico, Guará, Cruzeiro e Sobradinho. As profissões são diversas: professores universitários, concursados, autônomos, jornalistas, donas de casa, servidores públicos, nutricionistas, professores de dança, educadores físicos e outros. Quando procuraram a escola, buscavam um espaço com área externa; tempo na rotina para as crianças brincarem livremente; nenhuma tecnologia ou atividades com filmes ou desenhos animados; uma escola com proposta alternativa que tivesse vagas para crianças da idade das suas e as acolhesse; um lugar onde pudessem ter liberdade, mas fossem orientados de alguma forma com regras e combinados; e que oferecesse uma alimentação saudável. Essas eram questões que as famílias traziam no momento da entrevista e da visita à escola.

As educadoras são recém-formadas que ou estão em seu primeiro emprego ou trabalharam em outras escolas como auxiliar e queriam uma oportunidade para ser professoras. Todas tiveram trajetória escolar em ambientes tradicionais de ensino, e suas formações acadêmicas também incluem essas visões e linhas pedagógicas, questões que trazem ao fazer a entrevista para o processo seletivo e depois no dia a dia. Elas demonstram muito interesse em ver como funciona um espaço com tais propostas inovadoras, pedem auxílio para se adaptar e saber mais sobre como fazer e o que propor para as crianças. Atualmente, são quatro professoras - três delas pedem para ficar o dia inteiro na escola a fím de complementar sua renda - e quatro estagiários, um homem e três mulheres, duas delas também optantes pelo horário integral. Ainda compreendidos como educadores, de acordo com a filosofia e proposta da escola, estão duas auxiliares da limpeza e cozinha; um funcionário do jardim e serviços gerais; e as duas coordenadoras - também mãe e filha e idealizadoras do projeto. Integram a equipe as professoras e professor do Projeto MusiMultidisciplinar e o professor de capoeira e danças afro-brasileiras.

As respostas para os problemas educacionais não estão somente nos livros, nos meios acadêmicos, nas palavras dos teóricos mais renomados e, muito menos, nas soluções sistematizadas e entregues para ser aplicadas. Os projetos e a reinvenção da escola estão na coragem do fazer. Assim como o nascimento de uma criança é único, especial, misterioso e incomparável, a construção de cada escola também o é. O que vai ser construído em cada espaço escolar pode ser uma verdadeira concha que vai sendo polida, cortejada, crescendo e se abrindo em seu tempo com suas particularidades, em um fazer com o outro. E só assim seu conteúdo pode deixar de ser areia e tornar-se pérola. Construir uma escola, nesse sentido, não apenas para sua inauguração, mas a cada dia, requer, antes de tudo, que se faça a partir dos sujeitos envolvidos naquele espaço em uma relação de corresponsabilidade, autonomia construída, solidariedade, amorosidade e, principalmente, de respeito ao outro. Assim, essa pesquisa se caracteriza por questionar como se dão os processos de pais, mães, educadores e crianças na construção de um espaço escolar inovador.

A contribuição deste trabalho para a prática social é pensar (ou repensar) a educação de outra perspectiva, pois se percebem muitas lacunas, queixas e dificuldades enfrentadas pelos educadores, pais, mães e crianças em seu cotidiano nas escolas. Ainda sobre essa questão, é importante ressaltar que espaços com práticas pedagógicas inovadoras, abertura para as famílias no funcionamento da escola e princípios de uma educação por meio da natureza estão sendo cada vez mais requisitados. Por outro lado, entretanto, as famílias ainda esbarram na dificuldade de encontrar espaços com esses princípios, e as iniciativas educacionais que por eles se pautam enfrentam desafios consideráveis para acontecer e acolher essas famílias. Cabe lembrar ainda o desconhecimento de grande parte de pais e mães que, apesar de desejar escolas como essas, não sabe como isso pode ser feito ou - ainda - que existem outras possibilidades de educar que fogem ao ensino tradicional.

Nesse sentido, a relevância teórica da pesquisa está em apontar para uma carência de reconhecimento de conhecimento justamente sobre essa questão, visto que ainda são poucos os espaços escolares que se propõem a modificar e reinventar sua prática porque não sabem como fazer, já que é vagarosamente que a academia está se abrindo para estudos e pesquisas que se delineiam nessa perspectiva - o que se pode perceber ao buscar teses, artigos ou dissertações em plataformas científicas. O 
aumento da produção sobre os processos de construção de um espaço escolar inovador por seus membros, que a pesquisa representará, pode, além disso, contribuir para a disseminação e o acesso de pessoas que procuram outras práticas pedagógicas cujos enfoque e reflexão se vêm fazendo necessários em um momento importante de reinvenção da educação pública e particular.

A importância metodológica do estudo ora proposto está no fato de pensar os processos apresentados de uma posição específica e ainda inovadora nas pesquisas, a de pesquisador que abre mão de uma visão hierarquizada que aplique a contribuição dos autores lidos e o conhecimento adquirido, simplesmente. Ou que busca respostas para perguntas previamente estabelecidas. Assim, a cartografia encontra lugar nessa pesquisa e aponta para novos olhares e perspectivas de compreensão.

Por fim, participaram dessa pesquisa três educadoras de um espaço escolar inovador em construção coletiva no Distrito Federal. As crianças participam da pesquisa através do olhar da pesquisadora transposto para o diário de campo, bem com por meio das observações feitas e das falas dos outros participantes. O critério de escolha dos educadoress foi o fato de que estivessem trabalhando nesse espaço escolar em 2017. Não participaram educadores que então não faziam parte do corpo docente nem famílias - compreendidas aqui como mães, pais e/ou filhos(as) - que se relacionavam com esse espaço escolar sem participar de suas atividades (reuniões e mutirões) e/ou gestão. Essa escolha deveu-se ao entendimento de que é necessário que educadores estejam ativos no processo de construção coletiva desse espaço escolar para se alcançarem os objetivos propostos na pesquisa.

Em se tratando de uma cartografia e, portanto, "não mais um caminhar para alcançar metas prefixadas (metá-hódos), mas o primado do caminhar que traça, no percurso, suas metas" (Passos \& Barros, 2015, p.17), foram realizadas cinco entrevistas semiestruturadas com pais e mães, pretendendo-se entender como percebem o papel da escola na sociedade contemporânea em que vivem e como pode essa ser feita em um processo coletivo de construção; três entrevistas semiestruturadas com educadores a fim de compreender suas concepções sobre o papel do educador e suas singularidades na prática pedagógica de um espaço escolar inovador; o diário de campo da pesquisadora e sua observação participante com escritas que auxiliaram a compreensão da processualidade dessa construção coletiva e particularidades que as crianças demonstraram em determinados momentos; e as rodas de conversas nos encontros com educadores e famílias com intenção de perceber mais um momento de troca entre esses sujeitos, cujos relatos sobre situações que vivenciaram foram então colhidos.

Para a participação nessa pesquisa foi solicitado que os entrevistados e participantes das rodas de conversa assinassem o Termo de Consentimento Livre e Esclarecido; tendo sido informados sobre os objetivos e com a possibilidade de ser acolhidos em possíveis questões que pudessem apresentar, assim como a assinatura dos responsáveis de um Termo de Consentimento Livre e Esclarecido para participação das crianças.

Em resumo, a construção das informações deu-se a partir de três situações: as entrevistas semiestruturadas com as famílias e as educadoras; as observações registradas no diário de campo da pesquisadora; e as observações realizadas nas reuniões com essa comunidade escolar.

As informações construídas foram analisadas e discutidas sob a perspectiva da teoria histórico-cultural de Vygotsky, utilizando-se como inspiração metodológica a Pesquisa-Intervenção da Cartografia; para a análise do material produzido entrevistas, relatos de campo, registros sobre as rodas de conversas - essa pesquisa inspirou-se na Análise de Conteúdo (Bardin, 2009) e em reflexões feitas no compartilhamento com o grupo do Programa de Pós-Graduação do Laboratório Ágora Psyché, de que a pesquisadora participa, bem como desenvolveu análise ao longo da pesquisa, como recomendado no processo de pesquisar pela cartografia.

A escolha desse procedimento deveu-se à possibilidade de permitir que o pesquisador interpretasse as informações construídas ao longo do processo, tendo conhecimento das percepções e contradições que aparecem via os instrumentos de construção das informações. Após esse processo de leitura, foram criadas categorias de análise para que o pesquisador desse andamento a mais uma leitura que permitiu agregar as falas dos participantes, então analisadas com fundamento na teoria que embasa a pesquisa. 
As informações obtidas foram pensadas com base no referencial teórico a fim de problematizar e refletir acerca das questões da pesquisa, mantendo, porém, em aberto espaço para novos questionamentos e direções que a cartografia, enquanto processo de caminhar dentro dessa pesquisa, pudesse trazer.

\section{Resultados e Discussão}

Para a análise das entrevistas realizadas com as educadoras do espaço escolar focalizado, a pesquisadora as reuniu em oito categorias criadas com base em seu aparecimento no estudo categórico sobre todas as falas dos entrevistados e que se mostraram reflexo das questões trazidas pelas entrevistadas a partir das perguntas geradoras feitas pela pesquisadora. Fez-se uma análise complementar com os relatos registrados no diário de campo da pesquisadora que têm relação com as categorias selecionadas, a fim de fazer sentido e que conversem.

\section{Paternidade e maternidade na sociedade contemporânea}

Hoje isso é uma ruptura muito forte, porque os pais vão trabalhar, as mães ficam aqui muito tempo, e elas têm esse estranhamento com o mundo e se sentem inseguras, têm medo; elas não têm muito contato, e aqui, por ser pequeno, a gente dá importância ao brincar; a gente dá muito tempo de brincadeira, uma hora e meia (EDUCADORA A).

Na fala dessa educadora é possível perceber questões que os próprios pais e mães trazem a esse respeito. A relação que a família tem com o trabalho faz com que deixe seus filhos e suas filhas na escola durante um tempo prolongado do dia, o que provoca nas crianças - sobretudo nas pequenas - alguns sentimentos como medo e insegurança sobre o lugar que habitam. Notase ainda a importância dada aos momentos de brincadeira e ao olhar mais íntimo para a criança; entendo que isso pode auxiliála a sentir-se segura no ambiente escolar. Referindo-me ao diário de campo, em uma de minhas conversas com uma das mães da escola, ela me dizia que estava tendo um processo muito difícil em sua casa, de mudança de rotina e de tudo o que as crianças costumavam fazer - comer sozinhas, dormir em suas camas, brincar entre elas quando todos estavam em casa à noite - e que, com a entrada na escola as duas filhas estavam demonstrando uma saudade de casa que não tinham antes. E ela se sentia culpada por ter que deixar as crianças na escola, mas o que lhe acalmava o coração era chegar na escola e ver que as filhas estavam bem, estavam felizes, que tinham amigos e amigas que brincavam com elas, mas, principalmente, porque as professoras e monitoras eram carinhosas e faziam parecer que suas filhas estavam em família. Então com todas as dificuldades que estava passando, tinha que "aguentar a barra" pois sabia que ia passar.

\section{Formação e prática docente "intuitiva"}

Hoje, como professora, posso dizer que as coisas não são tão simples como mostram os livros, que muita coisa a gente só entende vivendo (EDUCADORA B).

Na faculdade, as monitoras, as professoras mesmo formadas... A faculdade não tem prática educacional, não tem vivência. Deveria ser igual médico que faz residência e vai para dentro do hospital. Os professores deveriam ir para dentro de uma escola. É muita teoria, para zero prática, então, quando elas chegam em sala de aula, elas não têm ritmo de sala de aula, elas se sentem coagidas pelas crianças; então muitas vezes elas não se colocam no lugar desse mestre (EDUCADORA A).

Para mim, assim, eu não faço muita reflexão sobre isso não; para mim a teoria, na verdade, vem de uma forma bem prática, é espontâneo, eu vejo que eu tenho essa facilidade, digamos assim; eu tive filha jovem, eu tinha 18 anos, e eu vejo que desde então eu fui me separando do grupo da minha idade, porque eu já queria dar uma atenção, já me envolvi muito cedo com a maternidade; nesse sentido, então, eu já fui priorizando algumas coisas, mesmo eu tendo outra filha aos 30, eu vejo que desde muito cedo eu já tinha uma relação com a minha filha de práticas inovadoras, digamos 
assim; então eu aprendi um pouco com meu pai, que tambem é uma pessoa que tem muitos irmãos, que tambem é uma pessoa que procura trazer um outro modo de vida (EDUCADORA A).

De certa forma, sim, a prática é muito momento; ali, como você lidar com as situações; mas a teoria te dá um norte, de como você deve agir, porque vem da filosofia como você vai mediar as situações, conversar com a criança; eu acho que daria um apoio maior, eu estaria mais amparada (EDUCADORA C).

Tem toda a teoria que eu vi, que acho bacana, eu gosto muito de psicologia, mas acho que vai muito do momento de tentar mediar a situação ali. Não que eu me lembre de usar alguma teoria especifica, "ah, eu vou usar essa teoria", sabe? É mais o dia a dia mesmo, mais o conversar, e cada dia é uma surpresinha, um pacote de surpresas, um presente mesmo, e aí você vai vivendo, vai vendo como você pode lidar, como você vai lidar com a situação, como a criança vai lidar com o que aconteceu (EDUCADORA C).

acho que te dá uma base, um norte de você ver e você lembrar que fulano falou disso ou de que faz parte de um processo no qual a criança está realmente participando, só que ele não te explica como agir na situação; ele fala que é isso por causa disso e disso, mas... e aí? eu vou fazer o quê? E aí você se vira... e aí? o que adianta ele ter me explicado o que é aquilo que ela está vivendo, se eu não vou saber como agir naquela situação? (EDUCADORA B).

Nessas seis falas, as educadoras ressaltam a relação da teoria e da prática. Aparentemente, sentem dificuldade ainda de encontrar em sua formação um ponto em comum; um ponto na teoria que se possa traduzir na prática e um desejo de, na prática, encontrar a teoria. Também apontam que quando estão em sala de aula, já formadas como professoras, tendem a adotar práticas “intuitivas” com as crianças. Fazem aquilo que sentem ser o melhor e assim se relacionam com seus alunos e com o aprendizado. As experiências de vida de cada uma também são fontes essenciais para suas práticas, uma vez que em diversos momentos, remetem-se a alguma atitude de um familiar ou a algo que já viveram fora da escola. Em nossas reuniões de coordenação, quando discutíamos sobre alguma criança - algo que ela fizera e as professoras pediam ajuda para resolver, como uma briga com coleguinhas, por exemplo - tentávamos abordar alguma teoria, e certo dia uma professora que estava muito envolvida na situação nos disse "é, realmente... agora que vocês estão dando o exemplo que eu vivi, faz todo o sentido esse texto que vocês estão dizendo" (Diário de campo).

Imagino que algumas coisas que eu faço não sejam tão diferentes de uma escola tradicional, mas uma coisa que sempre me acalma é saber que a forma de olhar para as crianças é diferente (EDUCADORA C).

Nesse discurso, a educadora declara carregar atitudes "tradicionais" em sua prática, mas ressalva que sua forma de olhar para a criança faz diferença em seu trabalho. Nessa construção de práticas com as crianças, em reuniões coletivas, sempre voltávamos aos assuntos de como adotar quais posturas diante de situações que eram rotineiras com as crianças - mordida, dividir brinquedo, despedir-se da família ao chegar, por exemplo - e quase sempre começávamos a abordar a questão com "lá onde eu trabalhava, fazíamos dessa forma" - e daí partíamos para pensar o que poderia ser diferente, por que não fazer de tal maneira e como criar outras formas de comunicação e acolhimento (Diário de campo).

Não sei, é mais dessa questão de você estar trabalhando e você ter que ajudar, que isso faz parte da sua prática, aí você vai ajudando, aí você tem outros compromissos, aí você vai deixando de lado, e acaba que você vai fazendo no automático, muitas coisas vão saindo no automático do dia a dia, mas que você não sabe exatamente o porquê; vocêe sabe que está fazendo o bem, o certo, mas o que baseia aquilo você não sabe; você faz porque você já acostumou e aprendeu daquele jeito (EDUCADORA B).

Mais uma vez, o trabalho docente aparece com práticas automáticas de ação. É possível observar que a reflexão sobre o que se está fazendo ou mesmo o motivo por que se está fazendo ganha menos força do que a demanda do dia a dia. A forma como cada professora conduz seu trabalho no cotidiano com as crianças, nas pequenas tarefas, traduz-se em bom senso individual e ajuda coletiva. 
3. A escola e a família educando as crianças: educação coletiva?

Percebi quanto as crianças foram se desenvolvendo, repetindo mais o que fazíamos, sentindo prazer nos momentos de brincadeira e tendo liberdade para demonstrar o que sentiam e queriam (EDUCADORA C).

Só uma vez que eu mandei uma agenda para um aluno que a mãe não gostou muito; acontece, não é?! E assim, é criança, às vezes a criança bate, se estressa e não sabe como lidar, como reagir, empurra e bate. Eu acho que a família tem que entender que faz parte do processo, tem que aprender a lidar também com isso. Foi uma coisa que a gente estava até conversando na reunião de pais no sábado, que eu achei muito interessante, que acaba que quando você está grávida, você idealiza uma criança perfeita, do que seu filho vai gostar, como ele vai ser, como ele vai agir, e na verdade a criança é um outro ser, é um outro indivíduo, com outras características, com outros jeitos, outras manias, e é uma criança que está aprendendo a lidar com tudo aquilo que ela está sentindo no momento. E acaba que os pais têm que aprender a lidar também com as crianças (EDUCADORA C).

A educadora retrata um desafio na relação com as famílias, pois que vive uma realidade que frequenta as salas de educação infantil - já que as crianças ao longo de suas fases de desenvolvimento estão também aprendendo a conviver e se relacionar em um meio social - e que nem sempre coincide com o que as famílias querem escutar a respeito de seus filhos e suas filhas. Aqui cabe a transcrição de um relato registrado no diário de campo e que bem ilustra a fala da educadora $\mathrm{C}$, mas sobretudo a complementa, apontando outra vertente da questão, que, se não é fácil para as educadoras, não o é também para mãe nenhuma: "hoje vivi uma situação um pouco difícil. Tive que conversar com uma mãe sobre a filha estar mordendo as outras crianças da sala, e ela não gostou do que ouviu. Disse-me que a professora não estava preparada para lidar com a situação e que estávamos tratando a filha como vilã da história. Contei-lhe que apenas tinha sido conversado com a criança sobre fazer dodói no amigo se ela mordesse. Como foi na hora que a mãe estava chegando para buscá-la, a criança começou a chorar excessivamente o que causou certo susto na mãe e em nós, que estávamos todas conversando com a criança sem problema nenhum. Depois que a mãe levou a filha para o carro, me chamou e pediu desculpas, dizendo que tinha percebido que a filha estava fazendo "um show" por causa da presença da mãe e pediu que eu mandasse seu pedido de desculpas para a professora também” (Diário de campo).

aqui o pessoal é muito tranquilo, as famílias são muito abertas ao diálogo, acho que assim, aqui existe um posicionamento deles em entender a gente como uma coisa que veio para somar, que veio para ajudar; são amigos, que estão ali para ajudar; eu noto muito, que algumas famílias que estão aqui hoje adotam essa postura, de ser muito cooperativo, de pensar coletivo; tem algumas exceções que você nota assim, "sou uma família, estou pagando seu salário, então eu quero isso"... pelo menos essa visão que eles passam para a gente quando vem pegar, quando vai levar... que conversam umas coisas, do coletivo mesmo, mas assim como amigos, mas não com aquela cobrança de você é professor, eu pago seu salário e você tem que fazer assim assim e assim (EDUCADORA B).

é muito ruim você trabalhar e você estar todo o tempo sofrendo uma pressão de que isso está certo, aquilo está errado; então eu acho que esse clima leve deles [das famílias] só ajuda sua postura (EDUCADORA B).

Na relação das professoras com a família, o ambiente aberto e coletivo permite que se sintam em conjunto no trabalho de cuidar das crianças. Não há uma visão de obrigação por conta da questão financeira que as famílias pagam, e ambos os grupos demonstram compreender seus papéis na relação que criaram. Vez ou outra temos que conversar com algumas mães que chegam na escola procurando algo que não tem - salas esterilizadas, ambientes emborrachados, álcool para passar em tudo o tempo todo, móveis cobertos de proteções - e até fazendo alguma reclamações de sol, grama que pinica o pé, formigas no jardim. Nesses momentos, temos que nos manter firmes na proposta pedagógica da escola e lembrar para aquela família o que nos propomos com "educar" e como fazemos isso (Diário de campo). Mesmo estando no início e precisando financeiramente - e obviamente por outros motivos - que as crianças estejam na escola, não podemos deixar para trás a proposta de educação que queremos em função de exigências descabidas para o lugar que queremos. É um risco, mas vale a pena. E, quase sempre, as crianças não demonstram incômodo ou desgosto. Pelo contrário, parecem que estão se sentindo livres como nunca foram. 
Há pais - na verdade, mães - que estão constantemente preocupados em criticar em vez de conversar ou aceitar as decisões coletivas. Há princípios que vêm sendo criados e que sustentam a prática pedagógica. Eles podem ser questionados e discutidos e, eventualmente, mudamos algumas práticas ou as aprimoramos. O que não podemos é aceitar que a escola mude todos os dias, como se troca de roupa. Temos que conversar, fundamentar nossas posturas em teorias e em posicionamentos éticos e políticos (Diário de campo).

\section{Gestão participativa: as relações de um trabalho coletivo}

Uma coisa muito interessante de trabalhar aqui é o fato de a escola ainda estar no começo, e dessa forma, a gente consegue viver muito os processos de criação para que essa possa se tornar uma escola diferente (EDUCADORA C).

Elas [as professoras contratadas] não conseguem abrir muito a cabeça, e elas têm essa necessidade de alguém que fique cobrando, orientando, dizendo eu estou aprendendo a fazer isso (EDUCADORA A).

Nesses dois trechos percebem-se pontos opostos da visão do trabalho coletivo. De um lado, a professora mostra-se com um sentimento de pertença ao grupo, sente-se bem-vinda à construção do espaço escolar em conjunto. De outro lado, outra professora coloca sua visão de que existe uma cobrança para que o trabalho seja orientado, mandado, cobrado para que aconteça. Em uma reunião, uma professora falou para mim “eu não queria voltar a ter tantas regras para seguir, não mesmo. Mas preciso de algumas. Você pode me dizer o que fazer? Eu já não sei como planejar atividades para esse mês e também queria que você conversasse com aquela mãe, porque estou tendo muita dificuldade com ela" (Diário de campo). Assim, é comum sentirem-se mais seguras se tiverem alguém que por elas responda. Às vezes é complicado ser sempre você a tomar as rédeas das situações.

eu enfrento vários desafios, como... assim, eu não gosto de ser dona, eu detesto hierarquia, desde pequena na escola já não gostava, no grêmio eu nunca gostei de ir lá, mas eu fui aprendendo a importância e a necessidade de um bom gestor, de um bom líder, pois um bom líder faz toda a diferença, e hoje eu costumo falar isso para mim mesmo, porque se eu conseguir aprender a dar o meu melhor e aprender a me expressar, poder orientar, na verdade eu estou ensinando, passando um conhecimento que outros vão poder aprender, mas isso para mim me custou porque, assim, eu não gosto de delegar, eu não gosto também de ter que ficar falando uma, duas, três vezes, de ter que ficar meio fiscal, ficar cobrando, eu não gosto disso, mas eu vi, tanto na área empresarial, lá de alimentos, como aqui, independe, de estar chegando e não ter essa experiência, não tem uma visão mais ampla (EDUCADORA A).

um dia uma funcionária, uma professora, falou pra mim: "então, chefe, o que que a gente vai fazer?", e ali caiu a ficha de que eu precisava me pôr nesse lugar, como dona, não é; porque é diferente a questão de ser administradora, de ser só professora, coordenadora, é diferente, e aí no início foi assustador, pois eu tinha que ver todos os detalhes, coisas muito pequenas, e como somos poucos, poucos recursos humanos e poucos recursos financeiros, então dá muito trabalho (EDUCADORA A).

Nas duas falas da professora, evidenciam-se a dificuldade e o desafio de colocar-se em uma posição de hierarquia em relação a outras pessoas que ela precisa coordenar e que dela demandam comandos e posições. É possível notar também como é importante a relação de troca quanto ao que as professoras levam para ela como necessidade; importante para que esse papel seja assumido, construído.

eu ainda me sinto na corda bamba, ainda não me sinto assim, estruturada, estou sempre assim, na corda bamba; então, como todo empresário, estamos sempre matando um leão por dia, mas eu me sinto muito bem e gosto quando as crianças me dão um retorno incondicional; então, quando eu vejo esse desenvolvimento delas, vejo esse potencial... eu tive esse retorno hoje; ontem eu tive ali com o menino, e aí eu levei ele e fomos dar comida para as galinhas, e aí ele abraçava e brincava com os pintinhos, e ele estava se sentindo seguro naquele espaço; isso me traz uma força... (EDUCADORA A).

Aqui, as professoras trazem um grande motivo de suas escolhas em trabalhar como professoras: a recompensa que as crianças lhe dão na vivência escolar. Um dia, decidimos fechar a escola. Não aguentávamos mais tantos problemas, tantas coisas 
para decidir, tanto trabalho. Estava mais pesado do que leve. Pois bem, naquele dia nos falamos por telefone e ficou decidido que levaríamos tudo até o final do ano. Quando chegamos no meio do ano, muitas famílias se interessaram pela proposta e quiseram se juntar a nós. Famílias novas, opiniões novas, energia nova. E foi tudo de que estávamos precisando. Sem saber explicar muito bem, sentíamos que era para ter sido sempre daquele jeito, com aquelas pessoas. Agora iria fluir! O alívio, a alegria e o sentimento de força para criar outras formas e abrir espaços de convivência foi tão grande, que decidimos continuar. Até um grupo de estudos os pais e as mães nos pediram para formar no ano seguinte! Amizades entre eles, sugestões positivas, enfim, um grupo que realmente pensava no melhor para todos (Diário de campo).

Eu acho que faz parte do processo tradicional de que eu vim também, porque, querendo ou não, na escola tradicional você é muito cobrado, a pressão é muito grande para todas as coisas darem certo, e quando eu vim para cá foi o contrário. As coordenadoras deixam a gente fazer do nosso jeito (EDUCADORA C).

A gente sempre tem o apoio de mostrar a elas e ver o que elas acham, é uma parte muito bacana, de parceria mesmo. Agora o que eu acho meio difícil é porque esse lado também tem um lado ruim. Você faz as coisas muito sozinha, às vezes você fica procurando "ah, eu posso fazer isso?", "já está na hora de fazer isso?” (EDUCADORA C).

Essas falas remetem aos processos da autonomia e do trabalho coletivo. Ora a cobrança amena é ponto positivo, ora deixa a desejar. Mas, como um processo, a abertura entre coordenação e professoras mostra-se caminho de comum acordo e possível de trabalhar. Uma monitora fez-me um pedido: "posso usar um gravador e ficar gravando as coisas que a fulana [coordenadora] fala? É tão lindo! Tanta coisa que eu não sei e nunca ouvi falar! As crianças ficam tão diferentes quando ela fala!" (Diário de campo).

Eu não sei se seria uma questão de organização em si, mas de um cargo que não tem como ser ocupado, que fica distribuído nas duas e as sobrecarrega (EDUCADORA C)

Como coordenação, ficam com um papel específico de correr atrás de tudo, de fazer acontecer mesmo, da organização do evento... e aí elas [as coordenadoras] chegaram já depois, na festa junina, por exemplo, aí as coisas já estavam mais montadas (EDUCADORA C)

E eu achei isso [a retirada das professoras do grupo do Whatsapp que agregava as famílias, a coordenação e as professoras] muito bacana, acho que foi a melhor decisão, porque acaba protegendo eu e a outra professora de problemas que têm que ser levados para a coordenação; há uma liberdade nossa com a família de responder: "o neném comeu, dormiu”, [coisa] de professor mesmo; as famílias são bem tranquilas, mas a gente tenta reportar muito para a coordenação: "ah, sobre isso quem vai poder te responder é a coordenação” (EDUCADORA C).

As professoras, aliás, resguardam-se atrás da coordenação em uma espécie de relação de confiança, acreditando que serão tomadas as melhores decisões e ajudando a construí-las.

É porque é difícil; a gente fala assim, a gente tem muito problema, e tem também que a gestão não é uma coisa fácil, não cria uma coisa do nada e daqui a um mês, dois meses vai estar tudo perfeito, não vai; porque você sabe que não é tão simples; eu acho que às vezes falta um pouco de..., não sei se é de atenção, ou se é de controle daquilo que você quer, de como você quer, de uma clareza de como você fala, que eu acho que isso é uma coisa que ajuda, porque às vezes é muito simples, mas por falta de falar e de conversar, não sai do jeito que as pessoas querem, e aí acabam rolando os problemas de uma gestão; eu acho que você tem que aprender a exigir aquilo que quer, e as pessoas também têm que aprender a falar e a cobrar o que querem; eu acho que não adianta nada eu falar que tem que melhorar isto e aquilo, se eu não sei falar, não me exponho ao falar; então, assim, eu acho que [precisa] tanto eu saber falar e saber pedir quanto a pessoa saber ouvir (EDUCADORA B).

Porque, se você está gerindo um negócio e tem pessoas trabalhando que você coloca naquela função, por mais que você confie, você tem que estar do lado, porque você precisa concordar ou não com aquilo que a pessoa esta fazendo, e se impor; se você não concorda, você se impõe e fala "não é assim por causa disso, disso e disso"- e não "porque não, porque não pode" -, e "é por isso, isso e isso"; e aí esse ano não, esse ano as meninas estão aqui todos os dias, elas já conversam, têm as reuniões que ajudam em relação ao planejamento, então assim, existe todo um processo que mudou do formato que era para oformato que temos hoje; mas assim, que isso eu acho que é o tempo, eu acho que as 
coisas vão falando, eu preciso disso e agora tem isso aqui que eu pedi porque eu soube chegar e falar e pedir, e elas souberam ouvir e entenderam a necessidade (EDUCADORA B).

A equipe é pequena, não somos muitos, mas acho que na medida do possível a gente tenta, acho que às vezes existe um problema assim com o horário e com acordos que às vezes a gente não cumpre, tanto da minha parte como de outras pessoas, então, assim, o trabalho coletivo, dentro de todos os furos que tem, ele vem com tranquilidade, a gente conversa a gente faz (...) eu acho então que tem que ter um comprometimento (EDUCADORA B).

Por fim, as falas da professora apontam melhorias para um trabalho coletivo mais claro, em que todos saibam e sintamse contemplados, bem como reconheçam o tempo e a necessidade de reconstruir ao longo do processo.

5. Os desafios e a vivência de um espaço escolar da experiência

Estagiei em uma escola particular, trouxe dessa experiência algumas bagagens que tive que abandonar (ainda bem) ao começar a trabalhar aqui (EDUCADORA C).

Sempre sonhei em trabalhar em um lugar onde pudéssemos respeitar o tempo da criança e "viver" essa criança que temos dentro de nós (EDUCADORA A).

Nossa! O que eu sinto trabalhando aqui? Me sinto leve. Não há cobranças excessivas e desnecessárias (...) nós construímos e confeccionamos tudo junto com as crianças. Trabalhar nessa escola é se sentir livre, você pode ser criança junto com seus alunos. É assim que me sinto, feliz. Em relação às dificuldades e desafios com os quais me deparo é realmente a insegurança de trabalhar com o que acredito, mas não me sentir preparada na teoria (EDUCADORA C).

Eu fiz estágio na escola tradicional, a creche também foi tradicional. Supertradicional, assim de criança de dois anos sentar à mesa e fazer atividade, papel e "essa é a letra A", "vamos fazer a letra B". [Esta escola] foi uma superdescoberta, superadaptação, porque é um mundo completamente diferente do tradicional, às vezes a coordenadora fala até hoje que eu fico meio fixa em horários, "não pode cair", "tem que tomar remédio", é uma preocupação muito grande, vinda da escola tradicional principalmente, e eu gosto muito de estar aqui (EDUCADORA C).

Eu lembro que eu ficava boquiaberta, "mas como assim, gente, a professora pode comer a comida dos alunos junto com eles, pode participar do lanche?!”, porque lá na outra escola não tinha isso, o lanche era para as crianças; hoje eu compreendo e superapoio, para você incentivar a criança a comer, você tem que experimentar. Na escola tradicional o menino não pode se sujar, não pode sujar a roupa, não pode sujar a manta, então foi uma adaptação muito grande. (...) mas logo a gente vai pegando o jeito, vai se adaptando, vai se tornando um processo mais natural, tanto o cair, o se sujar, tocar, conhecer; é mais tranquilo, mais natural mesmo; é da criança, faz parte do processo (EDUCADORA C).

E o processo da criança, acaba que quando você vem de uma escola tradicional, eu ficava muito naquela coisa: o menino não pode cair; não pode se machucar; não pode se arranhar; não pode ser mordido; não pode ter nada disso. É uma pressão psicológica muito grande, principalmente em cima de monitor que é quem está lá diariamente, assim de cuidar, de trocar roupa, e quando eu vim para [cá] eu dei uma relaxada, porque faz parte do processo, a criança tem que passar por isso também, vai acontecer querendo ou não (EDUCADORA C).

ficava um pouco perdida, ficava muito limitada de querer trazer coisas prontas; e a escola não tem essa sistemática dos meninos construir, dos meninos aprender, de se entender, de se aceitar do jeito que fazem, não é tão ruim, de não ser concreto, eu não posso trazer uma imagem pronta porque não tem a ver com propósito (EDUCADORA B).

gostar de estar no ambiente, o gostar de estar com as crianças... é o que me faz estar aqui, por assim [dizer]. É o que eu sonhava?!, não é! O ideal era eu estar mandando os meninos estarem sentados e me ouvindo e eu fazendo tudo lindo, só que não é; mas o gostar de estar com eles, de todo dia eu vir conversar, abraçar e rir. É o que me faz vir todos os dias; eu acho que é o amor à profissão mesmo assim que me mantém assim querendo, eu não vou te dizer assim que tipo, "ah, você não gosta de estar aqui" não, eu gosto, é legal e diferente do que você está acostumado assim, mas quando você constrói uma coisa na sua mente e precisa desconstruir é um processo muito longo, e para mim muito mais ainda, porque eu sou muito teimosa; é isso, é isso, "não é isso", não! Eu estou errada, mas eu digo que é isso. E para desconstruir isso demora um tempo (EDUCADORA B). 
quando eu vim para a entrevista [a entrevista de seleção para contratação], eu pesquisei o que era uma escola de método natural porque eu nunca tinha feito experiência nenhuma. Uma coisa é você ler, outra coisa é você vivenciar; aí eu li, cheguei lá na entrevista, fiz tudo, vim conversei e tal, aí eu entendi um pouco, mas é diferente você ler entender e você vir e vivenciar; aí eu falei assim, não, beleza, cheguei aqui aí eu vi que é bem diferente; tinha outra professora, que virou minha amiga, e nós conversávamos muito; então eu entendi. O que me fez entender assim mesmo foram esses diálogos com elas... ela me esclareceu como que era, e ela ia falando, e eu ia vendo na prática como era, agora ela já não está mais aqui, mas eu agora já consigo entender o porquê e como da criança ter o seu espaço. No semestre passado tiveram muitas palestras e nas que eu pude, eu participei, e me ajudou, porque, como você vem de um método muito tradicional, palestras com essas pessoas te ajudam a ter uma clareza maior do que é sua função aqui, não só como profissional, mas assim o mundo dessas pessoas. São famílias diferentes que pensam diferente das tradicionais (EDUCADORA B).

As educadoras demonstram estranhamento e curiosidade quando se deparam com outro jeito de fazer, outro modo de conceber a prática docente, as relações com as crianças, as relações com os limites e possibilidades. No início apontam ter grande dificuldade em se adaptar e rever conceitos e costumes. Mas, depois que se permitem indagar e experimentar, apontam diálogos marcados por alegria, esperança e contentamento de participar de algo diferente do que foram acostumadas em outras vivências de trabalho.

\section{Concepções e reflexões sobre a infância}

É por elas que tento fazer o melhor trabalho possível, por elas e por uma sociedade melhor no futuro, que terá adultos melhores, porque tiveram sua infância respeitada (EDUCADORA A).

É comum perceber no discurso das professoras o amor e carinho que cultivam pelas crianças e a vontade de fazer melhor por elas; para elas.

Deixar as crianças brincarem livremente é algo diferente do que já tinha vivenciado. O espaço então... É algo pensado para o bem-estar das crianças! (EDUCADORA B).

Para tanto, permitem-se experimentar algo novo, uma proposta nova, observar como as crianças se comportam diante do espaço que lhes é dado. Quando começamos a escola, em todos os quatro espaços que já ocupamos, não chegávamos com tudo pronto. Tínhamos uma ideia inicial. Sabíamos que precisaríamos de um escorregador, um tanque de areia, balanços e brinquedos de areia para o parque. Nas salas queríamos o mais simples possível: um colchão com almofadas, uma casinha feita como uma tenda, fogãozinho, panelinhas, alguns livros, alguns brinquedos e uma mesa com cadeiras. Mas nada tinha seu lugar definido. As crianças podiam compor a sala como queriam. Arrastar, mudar, trocar. Misturar os brinquedos entre as salas dos grandes e dos pequenos. Compartilhar. Se elas quisessem trocar de sala por um tempo, também não havia problema. No parque, elas criavam seus cantinhos. Era um pneu, uns brinquedos, uns panos que davam lugar ao cantinho que queriam. E lá estava inventado um novo espaço. E observando onde elas gostavam de estar e sobre o que queriam brincar lá, elaborávamos uma casinha de madeira, um balanço de pneu para caber mais de uma criança, um tronco no chão para o trenzinho, alguns tocos de madeira com pneus para um carrinho, um pergolado para sombrear aquele canto tão preferido mas ensolarado, um brinquedo trepa-trepa para aqueles meninos gastarem energia depois de se entediarem com o restante. Até um banheirinho arquitetamos com as professoras depois de elas sugerirem para facilitar a logística da saída do parque para a sala. Do jeito que elas queriam: tanque alto (para não sentir dor nas costas) com escadinha, pia baixa e um banquinho em todo o redor para as crianças se sentarem e calçarem os chinelos (Diário de campo). Enfim, são só alguns exemplos do espaço sendo construído a partir das crianças. Haja visto que "quando propostas pedagógicas são apresentadas às crianças, por meio do lúdico, elas são estimuladas e convidadas a explorar movimentos, corpo e mente passando a ser protagonistas da sua própria identidade, aprendendo saberes de forma autêntica e satisfatória." (Rodrigues; Carvalho, p.9, 2021) 
sobretudo essa questão do desenvolvimento da criança de uma forma diferente do que a gente vê na academia; essa questão do corpo, do instinto, da personalidade dela eu aprendi muito com isso (EDUCADORA B).

E, com isso, ganhar novas maneiras de entender a infância, as suas manifestações, a formação das subjetividades infantis, outros modos de se relacionar com elas.

\section{Para que serve a escola}

essa questão de ouvir o próximo, de amor ao próximo, respeito, a questão até do perdão, não é? hoje as crianças ficam tão incomodadas, você encosta nelas, brinca assim e empurra, parece que ofende, é algo que elas se sentem violentadas, $e$ algo que é super-relativizado, não é? como é esse convívio, todo mundo passa por isso na humanidade (EDUCADORA A).

eu tenho tido retorno de crianças de cinco, seis anos todos os dias, e eu me pergunto isso, como que essas crianças estão aprendendo, o que estão fazendo com elas e assim; elas não conseguem o exercício que eu passei, que é, assim, ficar sentado, para lanchar, elas não conseguem ter concentração; e uma competição o tempo todo de uma desafiando a outra, "eu vou contar pro seu pai, eu vou dizer ..." é de delatar, e de dizer o meu é melhor, esse é meu, não tem uma ... e não tem concentração, começa uma brincadeira já quer outra, muito dispersa, e se joga no chão, não conseguem ficar sentadas em roda, alguns minutos; eu fico preocupada com isso, e ao mesmo tempo, quando a gente compara com valores educacionais, de outros países, a questão da necessidade da criança de ficar com um membro da família na infância, um período, o incentivo do educador, a importância do educador (EDUCADORA A).

como o brasileiro dá importância às aparências, então são escolas muito bem equipadas, têm brinquedos sempre novos, um recurso material muito grande, porém afetivo, muito pobre, muito pouco, e isso é o que a criança pequena mais precisa; então elas são muito carentes; em pouco tempo elas já me abraçam, já me escutam; ontem já me pediram "você pode ir para a minha casa?" "você pode ir para a minha escola?" "eu não quero ir embora", porque o pouquinho que você dá, que você estimula, você se aproxima, e a questão da cooperatividade, elas não estão aprendendo; e o que se fala tanto na empresa, a necessidade de ser cooperativa, a necessidade de ouvir o outro, a necessidade de ser criativo (EDUCADORA A).

só interagindo, dando afeto, carinho, dialogando. E também são turmas pequenas, isso facilita muito, então, essa criança que eu estou contando vive em um contexto de 25 crianças, e aqui ele está em um contexto de 12 crianças, ele é ouvido, ele pode prestar atenção, existe um silêncio, existe uma, dentro da rotina, existe uma rotina, ele tem espaço, então o educador ele interage, e ele tem que aprender todo esse afeto também, como se colocar nesse lugar (EDUCADORA A).

As quatro falas da professora ocupam um lugar importante quando se pensa o objetivo de um espaço escolar. Para que se está fazendo tal tarefa. Assim como aponta, por meio de sua experiência e relatos que ouve de adultos e crianças, as preferências que têm sido dadas para a educação infantil. E como essas se refletem em alguns comportamentos observados pela professora em seu cotidiano com as crianças em um lugar diferente do que elas estão acostumadas.

\section{A relação entre educar e cuidar}

Então em três dias ele já começou a falar alguns sons e está dormindo mais calmo, pois ele voltou mais tranquilo, e aí é um retorno que eu estou tendo das famílias, porque as crianças, elas não são daqui, e elas voltam mais calmas; então, uma das coisas que eu descobri que é uma diferença tão simples, do Rudolf Steiner, ele traz essa questão natural, que é a questão do conviver, de estar em grupo, que hoje em empresas se fala muito disso, não é? de trabalho organizacional, das inteligências emocionais, então eles dão um monte de nome, mas que simplesmente é você ter esse contato, é o tato, o contato, essa criança principalmente, por que eles estão aí no jardim de infância, para o mundo (EDUCADORA A).

O papel do educador, eu acho que vai muito da necessidade de você trazer os princípios básicos, noção de espaço, de tempo, do cuidar, igual eu converso com as crianças, não é voltado para o ler ou escrever, é mais para entender um pouco mais do que tem na vida, do que está perto dele, as coisas. Eu vejo como princípio básico do momento que está vivendo ali, o ambiente sociável (EDUCADORA B). 
As professoras tratam o que é educar de uma perspectiva até simplista nas relações. Questões mínimas de convivência, como o tato. Apresentam suas formas de ver o que é educar e cuidar de crianças pequenas. Convivendo com professoras e monitoras que muitas vezes estão em seu primeiro emprego, e ainda em uma escola inovadora - diferente daquilo que vivenciaram ou do que ouviram as pessoas falando - as indagações de “para que isso?” ou “o que eu estou fazendo aqui?” são muitas. E se vê nitidamente nas atitudes da pessoa quando ela não está entendendo, quando não está fazendo sentido para ela nada do que está sendo proposto pela escola. Essas não ficam; rapidamente, saem. Vão percorrer outros caminhos. Não só na equipe pedagógica isso acontece; nas famílias também. Às vezes, assim que a família chega para visitar a escola ou quando decide matricular por conta do preço ou porque achou legal ter poucas crianças, já sabemos que é uma família que não vai ficar muito tempo ou não vai entender boa parte do dia a dia. Esse, porém, é um processo muito pessoal, e cada um tem que descobrir por si. Acolhemos, explicamos e acolhemos também quando decidem sair (Diário de campo).

A gente acaba criando um vínculo de afeto muito grande; a maioria das crianças que ficam aqui pela manhã é integral, e eu fico integral também, então acaba que eu estou sempre aqui, as crianças estão sempre aí, e acaba que a gente vai aprendendo a lidar um com o outro, vai brincando junto. Quando eu cheguei tinha uns já do ano passado, então eles eram superapegados com a outra professora, porque ela já vinha do ano passado, então todo mundo já conhecia ela. Os novatos foram se chegando e pegando intimidade; agora todo mundo é família do mesmo jeito (EDUCADORA C).

Lembro-me perfeitamente de dois dias na escola: a saída de duas famílias que eram já como amigas. Eu e a outra coordenadora e dona da escola choramos juntas quando chegamos em casa e ficamos relembrando os passos que aquelas crianças deram, coisas que elas nos falavam, as brincadeiras que fazíamos juntas (Diário de campo). Durante a convivência que as educadoras têm com as crianças, laços de amizade e carinho são construídos com elas e com suas famílias. Por se tratar de um pequeno grupo, essas relações são mais estreitas e figuram-se quase como se fizessem grande parte de suas vidas.

A gente aplica as atividades, dá auxilio na realização das atividades, o cuidar em si, dar banho, trocar fralda, é muito meu papel também com os pequenos, é muito notório isso, tentar mediar as situações de conflitos entre eles, principalmente com os maiores, com os pequenos não tem muito. Mas também lidar com as frustrações das crianças; em diversos momentos elas se frustram e choram, se sentem insatisfeitas com alguma situação; estar ali para dar apoio, para deixar esse processo mais natural, porque faz parte da vida. A gente tem uma mãe que fala com os filhos "isso que você está sentindo é frustração, isso vai acontecer diversas vezes na vida”, e eu acho isso muito bacana, eu tento pegar um pouco disso também, porque a criança tem que ter noção do que ela está sentindo e aprender a lidar com aquele sentimento que está vindo nela: de raiva; angústia; dor (EDUCADORA C).

Trata-se, ainda, de trabalhar com as emoções das crianças, com o que vivem no dia a dia, com o que vivenciam nas suas relações com outras crianças. A professora mostra que o exemplo dado por uma mãe lhe possibilita acrescentar atitudes a sua prática e modos de ver.

Essa necessidade de cuidar, de estar junto, de rir, de cantar, porque alfabetização em uma escola tradicional ela é muito maçante, é um processo muito cobrado e muito difícil para a criança de descoberta mesmo, porque é um processo longo também, e nem sempre, sei lá, eu não sei se todas as crianças, ali da escola onde eu estava fazendo estágio, sentiam prazer em ser alfabetizadas, é meio tortura. Eu acho que seria interessante para [a escola] se tornar essa escola também (EDUCADORA C).

$\mathrm{E}$, pensando no que as pessoas acreditam quanto a poder fazer parte desse espaço escolar, onde se reinventam e aprendem diariamente com as crianças, com colegas de trabalho, com as famílias e consigo mesmas, fica o desejo de abarcar outras formas de educar também, como a alfabetização, para crianças maiores.

Na escola, a razão, e não a afetividade, tem sido colocada como prioridade, devendo o cognitivo ser altamente incentivado em detrimento da criatividade, liberdade e autonomia. A partir da crítica ao capitalismo, que pauta a educação pelas necessidades mercadológicas (Singer, 2010), têm surgido propostas de mudanças por parte de alguns grupos da sociedade, que defendem a educação em comunidades específicas. Esses movimentos de intelectuais e grupos sociais têm outras formas de 
educar. No âmbito da educação pública, foram propostas por governos progressistas políticas públicas voltadas para a superação da desigualdade social e para a inclusão de pessoas com necessidades específicas e para grupos sociais historicamente invisibilizados e excluídos.

No Brasil, como em muitos outros países do mundo ocidental, têm-se destacado movimentos educacionais conhecidos como Escolas Democráticas, Escolas Inovadoras ou Escolas Alternativas. Esses movimentos compartilham objetivos de desenvolver práticas diferentes das que existem na maioria das escolas, numa proposta contra-hegemônica, crítica da educação tradicional, excludente (Paulo Freire 2007, 2011). E todos desbravam caminhos inóspitos, fazem escolhas difíceis e necessitam de força coletiva para se inventar e reinventar.

Seja como for, o que vier a acontecer só ocorrerá nesse ambiente hiperestimulado e hiperestimulante, porque esse é o contexto no qual vivemos. Portanto, não se trata de verter todas as energias na tentativa de bloqueá-lo ou isolar-se, mas de tentar algo muito mais complicado e interessante: conceber modos de se subjetivar, pensar e dialogar nessas condições (Sibilia, 2012, p.92).

Neste trabalho, o que se propõe é que, na tentativa de construir outros modos de ser e de estar nesta sociedade, não se pode ignorar o que nela existe. É um desafio, pois que, mesmo em se tratando de pessoas dispostas e incumbidas de “fazer diferente", estão vivendo nesta cultura, nesta sociedade, neste momento histórico e nesta política da contemporaneidade. Isso inclui jeitos de ser, de se comportar, de viver e de se relacionar definidos por instituições e políticas bem estabelecidas. Além de tudo, é preciso quebrar paradigmas, "ir contra a corrente" e traçar na escola "espaços de encontro e diálogo, de produção de pensamento e decantação de experiências capazes de insuflar consistência nas vidas que as habitam" (Sibilia, 2012, p.211). Essas questões são encontradas na análise das falas das mães e dos pais em relação com as das educadoras em seu trabalho coletivo de educar as crianças e nos desafios de reconstruir uma perspectiva de educação.

Com relação às questões da maternidade e paternidade nesta sociedade contemporânea, "o que pode dar sentido à escola é da mesma natureza do que poder dar sentido às nossas vidas" (Pacheco \& Pacheco, 2014, p.35). Dessa forma, pais e mães encontram, em meio a vidas corridas, tempos dedicados a horas de trabalho e distância de seus filhos e suas filhas uma forma de se dedicar ao que acreditam ser melhor para suas crianças: lugares em que, enquanto eles trabalham, as crianças possam ficar, sentindo-se felizes, seguras, acolhidas e queridas. Espaços em que reconhecem a importância de sua participação, que, entretanto, eles veem limitada diante da realidade que se coloca na vida contemporânea.

Os professores e professoras, nessa caminhada coletiva por um espaço escolar inovador pautado na participação, ainda que em um contexto não associativo, trazem aquilo que Pacheco (Pacheco \& Pacheco, 2014, p.22) anuncia: “o professor é mais aquilo que faz do que aquilo que sabe. E é mais aquilo que é do que aquilo que faz. Os professores ensinam o que são". Logo, percebem-se faltosos de formação inicial que os pudesse ter munido de mais teoria correlacionada ou aplicável à prática das salas de aula; procuram nas vivências pessoais formas de educação e relação com as crianças; surpreendem-se com as novas maneiras de conceber o espaço, as atividades e o trabalho que um espaço inovador lhes permite viver; constroem e reconstroem suas subjetividades, valores e hábitos dia a dia em sua relação com o que são, com o que se exige deles e com o que querem ser, criando cada um sua prática docente, seja por meio da brincadeira, de conversas sobre suas vidas ou de olhar a infância com outros olhares. Visto que "essa possibilidade de aprender, como alguém que pode posicionar-se e apresentar seu modo único de exposição ao mundo, é ser considerado como 'capaz de...'; é sentir, em si mesmo, o princípio da igualdade de oportunidade ou, em outras palavras, tornar-se presença no mundo.” (Oliari, p.5, 2021). Além disso, percebem-se ativos no processo escolar dessa comunidade em que estão não para receber ordens e instruções prontas da coordenação ou das famílias, mas que possam questionar e sentir-se livres e com autonomia para caminhar em direção a soluções coletivas.

E nessa conversa entre famílias e educadores está um grande desafio de convivência, embora se saiba que "não se pode estar à espera de que tudo seja perfeito, mas tem que se olhar para quem trabalha conosco e sentir que existe um querer comum" 
(Pacheco, 2014, p.114). Esse querer comum, apontado pela pesquisa, é o desejo de acolher as crianças com amor, segurança e proximidade. Assim, estas duas esferas - escola e família - complementam-se reconhecendo, cada qual, a importância e o lugar da outra, dialogando para que os problemas sejam ajustados em conjunto e as alegrias possam ser elogiadas sem vaidades.

Arroyo (2012), sobre o olhar lançado à criança, pode ser compreendido em uma fala de uma educadora que traz seu contentamento em perceber que, por mais que faça seu trabalho sem saber muito bem se está inovando, acalma-se quando vê que sua forma de olhar para as crianças é diferente. Assim como a maneira de organizar o espaço físico da escola, os brinquedos e os lugares. Pulino (2001) elucida-nos quando fala da criança que se relaciona com o adulto em um movimento dependente e com isso os dois vão se constituindo conforme vão vivendo e tendo experiências. As mães, principalmente, idealizam situações, formas de cuidar e de viver com seus filhos e filhas ainda durante a gestação e, quando, após o nascimento, outras demandas externas exigem que aconteça tudo de outra maneira, sentem-se tendo que descontruir o que sonharam para encontrar um lugar que possa corresponder ao que seria próximo desse ideal que queriam para sua família.

Referindo-se ao lugar da experiência de tempo menos rígido e apressado - como apontado por Benjamin (1994) - todas as esferas da microcultura escolar vão sendo modificadas e impactando uma a uma até atingir um todo maior. "Os projetos são lócus de mudança na escola, de mudança familiar e social. A escola não muda a sociedade nem muda sozinha - a escola e a sociedade mudam em simultâneo" (Pacheco \& Pacheco, 2014, p.69). Juntando-se com pessoas que saibam conviver e estejam abertas à nova escuta pode-se pensar para que serve a escola e que lugar ela ocupa em suas vidas, lembrando que o exercício coletivo de um espaço escolar inovador detém muitas surpresas do desconhecido e, consequentemente, da mudança. Uma vez que "não se pode pensar sem alteridade e, sobretudo, não se pode viver sem a alteridade. Bastaria essa verdade para reler a história inteira das ideias pedagógicas, para abrir escolas e para propiciar práticas educativas” (Kohan, 2010, p.8).

A proposta da educação inovadora conquista os pais e as mães, mas as educadoras têm dificuldades em adotá-la e praticá-la porque não reconhecem seu trabalho como inovador - mesmo que o estejam executando - pela falta de teoria que as fortaleça em seu trabalho como professoras. Pedroza (2012) sugere a brincadeira como forma relevante de formação e trabalho continuado que possa ser feito com as educadoras - e todos os adultos e crianças - a fim de apontar espaço aberto de se colocar e constituir-se em coletivo. Nesse contexto, poderia ser uma boa proposta de intervenção a ser realizada.

Ao longo do desenvolvimento dessa pesquisa, através do olhar e da experiência da pesquisadora - compreendida também como mãe, educadora, coordenadora e idealizadora desse espaço escolar - foi sendo formado um conceito de escola inovadora enquanto aquela que acontece na participação das famílias e no trabalho do educador para constituir uma pequena sociedade em uma prática que valoriza o brincar livre, conscientização ambiental, práticas de liberdade e autonomia fomentando o protagonismo das crianças a partir do desejo delas, construindo novas formas de conviver, transformar e construir simbologias no movimento dessa força coletiva para que esse espaço se invente e reinvente no intuito de acolher as crianças com amor, segurança e proximidade.

\section{Considerações Finais}

A metodologia utilizada nessa pesquisa permitiu a abertura nela procurada e um reflexo do próprio processo da construção desse espaço escolar vivenciado pela pesquisadora, compreendendo que "a educação consiste nesse processo que propicia o encontro com o outro, com o mundo e consigo mesmo" (Pulino, 2016a, p.31). Esse encontro foi traduzido em espaço para que o processo da construção fosse respeitado, levando em consideração os princípios metodológicos que toda cartografia tem. A cartografia também expressou o lugar da pesquisadora dentro do trabalho, considerando-a parte importante e integrante da pesquisa.

Por se tratar de assunto complexo - considerando os diversos âmbitos que um espaço escolar implica - a pesquisa pode se tornar extensa e com muitas questões a abordar, não permitindo, dessa forma, aprofundar um ou outro ponto que poderia 
merecer atenção especial. Essa limitação da pesquisa proposta, no entanto, já sugere novos caminhos a percorrer, outras pesquisas a fazer, que surgem do trabalho inquietante e até provocativo de repensar um espaço escolar que seja inovador. Até por se tratar de crianças muito pequenas - entre um e quatro anos de idade - essa pesquisa não pôde incluir entrevistas com as crianças e, dessa forma, aponta para a importância de uma pesquisa que seja feita diretamente com elas.

Conclui-se que o enfrentamento pessoal de mudança de perspectiva e de concepções de mães, pais e educadores para fazer acontecer uma escola diferente daquela a que estão acostumados é uma tarefa desafiadora para todos e que traz muitas reconstruções dos motivos, dos objetivos e de onde se quer chegar.

A educação, por meio de processos de aprendizagem não só no campo cognitivo, mas afetivo, social, cultural, constitui, assim, o espaço/tempo por excelência para se refletir e atuar na formação de cidadãos, de pessoas que se humanizam e se socializam, através de processos de subjetivação, de singularização, em meio à diversidade (Pulino, 2016a, p.60).

O caminho é gratificante, cheio de relatos carinhosos, calorosos, acolhedores e positivos e que partem da observação da maneira como as crianças passam a viver e demonstrar, assim como as mudanças que as famílias começam a sentir em suas vidas. Também aparece um ponto importante em toda a pesquisa que é o fato de serem pessoas que procuram algo diferente do que vivem em sociedade. Estão procurando novas formas de conviver, outras possibilidade de construção do ser humano que pode passar a constituir-se com base em outros valores e organizações.

Na prática, este estudo auxilia os educadores dessa escola a visualizar sua trajetória, compartilhar medos, desafios, experiências, alegrias e soluções. Trazendo o que se mostra singular nesse contexto educativo que é o da autoformação, "pois o conhecimento que o docente tem de si reflete diretamente nas interações sociais e no desempenho em sala de aula" (Magalhães, Díaz-Rodrigues, Fagundes, Santos, Prado-Netto, Xará, Walhbrinck, Porto, p. 7, 2021) um olhar para si que possa transformarse para transformar o que está ao redor. Um caminho para professores e professoras de formação e melhoria de seu trabalho e das relações com as crianças.

Nossa reflexão neste texto indica-nos um caminho: começarmos por uma atitude de humildade, assumindo nossas limitações. A partir dessa atitude socrática - "Sei que nada sei!" -, podemos nos dispor a suspeitarmos de nossas certezas e a buscarmos experiências que nos coloquem em situações de estranhamento do mundo (Pulino, 2016a, p.74).

Também aponta para essas e outras pessoas que é possível ser diferente, inovar na educação e construir outros modos de ser nesta sociedade, bastando apenas começar saindo de onde se está, questionando as várias possibilidades de escolha em relação a para onde se quer ir e se agregando a outras pessoas que compartilham de uma proposta. Um espaço que possibilite a constituição e construção de famílias que se formam e constroem diversificadamente e em coletivo.

Fica apontado como sugestões de trabalhos futuros a elaboração de pesquisas que investiguem pelas perspectivas das crianças os processos que elas vivenciam em um espaço escolar inovador, visto que tanto pode ser observado dos relatos dos educadores. Dar voz e espaço para as crianças serem ouvidas é prática que lhes dá a dignidade e o respeito que merecem e a que têm direito; afinal, é por elas que esses espaços são pensados e organizados diariamente, nada mais justo do que pesquisar sob as suas perspectivas.

\section{Referências}

Althusser, L. (1985) Aparelhos ideológicos do Estado: notas sobre os aparelhos ideológicos do Estado (AIE). Rio de Janeiro: Edições Graal.

Arroyo, M. (2012). Imagens quebradas: trajetórias e tempos de alunos e mestres. 7 ed. Petrópolis: Vozes.

Bardin, L. (2009). Análise de conteúdo. São Paulo: Edições 70.

Benjamin, W. (2002). Reflexões sobre a criança, o brinquedo e a educação. São Paulo: Editora 34.

Benjamin, W. (1995). Obras escolhidas II: Rua de mão única. 5 ed. São Paulo: Brasiliense. 
Benjamin, W. (1994). Obras escolhidas I: Magia e técnica, arte e política. São Paulo: Brasiliense.

Dias, R. C. S. (2009). Relação homem-trabalhador: entre o bem e o mal-estar. Omnia Saúde, v.6, n.2, pp.1-14.

Freire, P. (2011). Pedagogia do oprimido. São Paulo: Paz e Terra.

Freire, P. (2007). Pedagogia da autonomia. São Paulo: Paz e Terra.

Gagnebin, J-M. (2004). História e narração em Walter Benjamin. 2 ed. São Paulo: Editora Perspectiva.

González Rey, F. (1999). A investigação qualitativa em psicologia: rumos e desafios. São Paulo: Educ.

Kohan, W.O. (2010). Devir-criança da filosofia: infância da educação. Belo Horizonte: Autêntica.

Kohan, W.O. (2005). Infância. Entre educação e filosofia. Belo Horizonte: Autêntica.

Larrosa, J. (2016a) [2014]. Notas sobre a experiência e o saber da experiência. In: Larrosa, J. Tremores: escritos sobre experiência. Belo Horizonte: Autêntica, pp.15-34.

Larrosa, J. (2008). Desejo de realidade - experiência e alteridade na investigação educativa. In: Kohan, W. O. Filosofia, aprendizagem e experiência. Belo Horizonte: Autêntica, pp.185-193.

Larrosa, J. (1999). Pedagogia profana: danças, piruetas e mascaradas. Trad. Alfredo Veiga-Neto. 2 ed. Belo Horizonte: Autêntica.

Magalhães, T.C; Díaz-Rodriguez, F. M.; Fagundes, D. D. A.; Santos, M. O. F. de; Prado-netto, A.; Xará, G.M.S; Xará, F.B.N.de; Walhbrinck, E. R. (2021). Educação inclusiva: autoconceito profissional de professores. Research, Society and Development, v.10, n.11, e406101119888, p.1-15.

Mitrovitch, C. (2007). Experiência e formação em Walter Benjamin. Dissertação (Mestrado em Educação). Faculdade de Ciências e Tecnologia. Universidade Estadual Paulista. Presidente Prudente.

Morin, E. (2011). Os sete saberes necessário à educação do futuro. 2 ed. rev. São Paulo: Cortez; Brasília: Unesco.

Oliari, G. (2021). A escola e a igualdade de oportunidades: alguns apontamentos para a reflexão. Research, Society and Development, v.10, n.11, e406101119888, p.1-12.

Pacheco, J. (2012). Dicionário de valores. São Paulo: Edições SM.

Pacheco, J. \& Pacheco, M. (2014). Diálogos com a Escola da Ponte. Petrópolis: Vozes.

Passos, E. \& Barros, R. B. (2015). A cartografia como método de pesquisa-intervenção. In: Passos, E.; Kastrup, V. \& Escóssia, da L. (Org.). Pistas do método da cartografia: pesquisa-intervenção e produção de subjetividade. Porto Alegre: Sulina, pp.17-31.

Pedroza, R. (2012). Infância e professores no espaço da brincadeira: possibilidade de formação. In: Pulino, L. H.; Gadelha, S. (Org.). Biopolítica, escola e resistência: infâncias para a formação de professores. Campinas: Alínea.

Rodrigues, C. F. de A.; Carvalho, E. T. de. (2021) A importância das práticas docentes enfatizando o lúdico como estratégia metodológica de ensino. Research, Society and Development, v.10, n.11, e406101119888, p.1-11.

Pulino, L. (2016a). Diversidade cultural e ambiente escolar. In: Pulino, L.H.C.Z.; Soares, S. L.; Costa, C.B.; Longo, C.A; Sousa, F.L.de. (orgs.). Educação e Diversidade Cultural (2016a). Brasília: Paralelo 15, pp.29-75.

Pulino, L.H.C.Z. (2012b). Resistência e criação na formação de professores: ouvindo outras vozes. In: L. H. Pulino; S. Gadelha (Org.). Biopolítica, escola e resistência: infâncias para a formação de professores. Campinas: Alínea.

Pulino, L. H. C. Z. (2001a). Acolher a criança, educar a criança: uma reflexão. Em Aberto, 18(73), pp.29-40.

Pulino, L.H.C.Z. (2001b). Gestão democrática na instituição de educação infantil: a experiência da Vivendo e Aprendendo. Em Aberto, Brasília, 18 (73), pp.131134.

Saviani, D. (1999). Escola e democracia. 32 ed. Campinas: Autores Associados.

Sibilia, P. (2012). Redes ou paredes: a escola em tempos de dispersão. Rio de Janeiro: Contraponto.

Veiga-Neto, Alfredo. (2005) Foucault\&Educação. 2 ed. Belo Horizonte: Autêntica.

Vygotsky, L. (2007). A formação social da mente. São Paulo: Martins Fontes.

Vygotsky, L. (2001). Psicologia pedagógica. São Paulo: Martins Fontes.

Vygotsky, L. (1991). Psicologia e pedagogia - bases psicológicas da aprendizagem e do desenvolvimento. São Paulo: Editora Moraes. 